\title{
Record of Decision Remedial Alternative Selection for the D-Area Burning/Rubble Pits (431-D and 431-1D)
}

by

E. R. Palmer

Westinghouse Savannah River Company

Savannah River Site

Aiken, South Carolina 29808

J. T. Mason

This paper was prepared in connection with work done under the above contract number with the U. S. Department of Energy. By acceptance of this paper, the publisher and/or recipient acknowledges the U. S. Government's right to retain a nonexclusive, royalty-free license in and to any copyright covering this paper, along with the right to reproduce and to authorize others to reproduce all or part of the copyrighted paper. 


\section{DISCLAIMER}

This report was prepared as an account of work sponsored by an agency of the United States Government. Neither the United States Government nor any agency thereof, nor any of their employees, makes any warranty, express or implied, or assumes any legal liability or responsibility for the accuracy, completeness, or usefulness of any information, apparatus, product, or process disclosed, or represents that its use would not infringe privately owned rights. Reference herein to any specific commercial product, process, or service by trade name, trademark, manufacturer, or otherwise does not necessarily constitute or imply its endorsement, recommendation, or favoring by the United States Government or any agency thereof. The views and opinions of authors expressed herein do not necessarily state or reflect those of the United States Government or any agency thereof.

This report has been reproduced directly from the best available copy.

Available to DOE and DOE contractors from the Office of Scientific and Technical Information, P. O. Box 62, Oak Ridge, TN 37831; prices available from (423) 576-8401.

Available to the public from the National Technical Information Service, U. S. Department of Commerce, 5285 Port Royal Road, Springfield, VA 22161. 


\section{DISCLAIMER}

Portions of this document may be illegible electronic image products. Images are produced from the best available original document. 
United States Department of Energy

Savannah River Site

Record of Decision

Remedial Alternative Selection for the

D-Area Burning/Rubble Pits (431-D and 431-1D) (U)

WSRC-RP-96-867

Revision 1

February 1997

Westinghouse Savannah River Company

Savannah River Site

Aiken, SC 29808

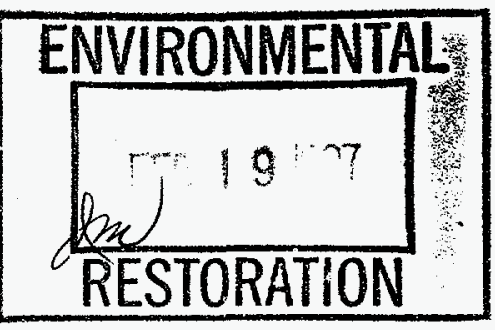

Prepared for the U. S. Department of Energy under Contract No. DE-AC09-86SR18500 
This page was intentionally left blank. 


\section{RECORD OF DECISION \\ REMEDIAL ALTERNATIVE SELECTION (U)}

D-Area Burning/Rubble Pits (431-D and 431-1D)

WSRC-RP-96-867

Revision 1

February 1997

Savannah River Site

Aiken, South Carolina

\section{Prepared by:}

Westinghouse Savannah River Company

$$
\text { for the }
$$

U. S. Department of Energy Under Contract DE-AC09-96SR18500

Savannah River Operations Office

$$
\text { Aiken, South Carolina }
$$


Recd of Decision for the D-Aren Burning/Rubble Pits (431-D and 431-1D)

Savannah River Site

February 1997
WSRC-RP-96-867

Revision 1

Declaration

This page was intentionally left blank. 


\section{DECLARATION FOR THE RECORD OF DECISION}
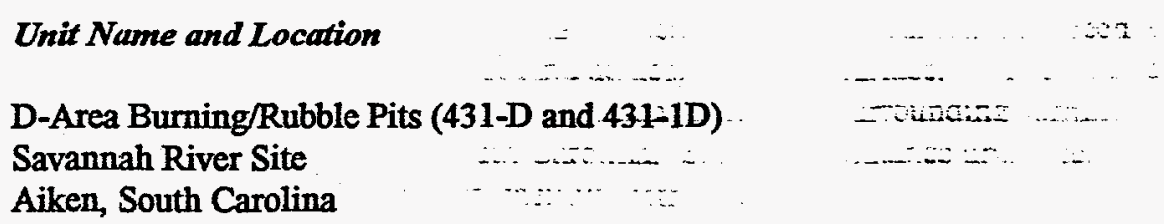

The D-Area Burning/Rubble Pits (DBRP) (431-D and 431-1D) Waste Unit is listed as a Resource Conservation and Recovery Act (RCRA) 3004(u) Solid Waste Management Unit/Comprehensive Environmental Response; Compensation and Liability Act (CERELA) unit in Appendix $C$ of the Federal Facility Agreement (FFA) for the Savannah River Site (SRS).

\section{Statement of Basis and Purpose}

This decision document presents the selected remedial alternative for the DBRP located at the SRS in Aiken, South Carolina. The selected alternative was developed in accordance with CERCLA, as amended, and to the extent practicable, the National Oil and Hazardous Substances Pollution Contingency Plan (NCP). This decision is based on the Administrative Record File for this specific RCRA/CERCLA unit.

\section{Description of the Selected Remedy}

The preferred alternative for the DBRP source operable unit soils is Institutional Controls which will restrict this land to future industrial use. Additional groundwater monitoring, as discussed in Section IX of the ROD, vill also be conducted. Based on the groundwater monitoring history, the probable condition is that no significant groundwater contamination has originated from the DBRP. Thus, no remedial action and a period of continued monitoring for confirmation is the only appropriate action for the groundwater at the DBRP. In the event that the probable condition of the local groundwater is no longer appropriate, DOE will evaluate the need for remedial action. Implementation of the Institutional Controls alternative will require both near- and long-term actions which will be protective of human health and the environment. For the near-term, signs will be posted at the waste unit which indicate that this area was used for the disposal of waste material and contains buried waste. In addition, existing SRS access controls will be used to maintain the use of this site for industrial use only.

In the long-term, if the property is ever.transferred to non-federal ownership, the U.S. Government will create a deed for the new property owner which would contain information in compliance with Section 120(h) of CERCLA. The deed would include notification disclosing former waste management and disposal activities as well as remedial actions taken on the site, and any continuing groundwater monitoring commitments. The deed notification would, in perpetuity, notify any potential purchaser that the property has been used for the management and disposal of construction debris and other materials, including hazardous substances.

The deed would also include deed restrictions precluding residential use of the property. However, the need for these restrictions may be reevaluated in the event that contamination.no longer poses an unacceptable risk under residential use. In addition, if the site is ever transferred to non-federal ownership, a survey plat of the area will be prepared, certified by a professional land surveyor, and recorded with the appropriate Barnwell County recording agency.

The post-ROD document, the Corrective Measures Implementation/Remedial Action Report (CMI/RAR), will be submitted to the Regulators four months after the issuance of the ROD. The CMI/RAR will contain a detailed monitoring strategy which will outline the submittal schedule and contents of the 
periodic monitoring reports to include: an analysis of the data, a conclusion, and a recommendation. The regulatory review period, SRS revision period, and final regulatory review and approval period will be 90 days, 60 days, and 30 days, respectively.

The South Carolina Department of Health and Environmental Control has modified the SRS RCRA permit to incorporate the selected remedy.

\section{Statutory Determination}

Based on the DBRP RCRA Facility Investigation/Remedial Investigation (RFI/R) Report and the BRA, the DBRP source operable unit poses no significant risk to the environment and minimal risk to human health. Therefore, a determination has been made that-Institutional Controls are sufficiently protective of human health and the environment for the remaining contamination in the DBRP soils and groundwater. The selected remedy is protective of human health and the environment, complies with Federal and State of South Carolina requirements that are legally applicable or relevant and appropriate to the remedial action, and is cost-effective. The random distribution and low levels of contamination preclude a remedy in which treatment is a practical alternative. Because treatment of the principal threats of the site was found to be impracticable, this remedy does not satisfy the statutory preference for treatment as a principal element.

Institutional Controls will result in hazardous substances, pollutants, or contaminants remaining in the waste unit. Section 300.430 (f)(4)(ii) of the NCP requires that a Five Year Review of the Record of Decision be performed if hazardous substances, pollutants, or contaminants remain in the waste unit. The three Parties have determined that a Five Year Review of the Record of Decision for the DBRP will be performed to ensure continued protection of human health and the environment.

Date

Date

Date

\author{
Thomas F. Heenan \\ Assistant Manager for Environmental Quality \\ U. S. Department of Energy, Savannah River Operations Office
}

John H. Hankinson, Jr.

Regional Administrator

U. S. Environmental Protection Agency

\author{
R Lowis Shaw \\ Deputy Commissioner \\ Environmental Quality Control \\ South Carolina Department of Health and Environmental Control
}


D-Area Burning/Rubble Pits (431-D and 431-1D)

WSRC-RP-96-867

Revision 1

February 1997

Savannah River Site

Aiken, South Carolina

Prepared by:

Westinghouse Savannah River Company

for the

-.U. S. Department of Energy Under Contract DE-AC09-96SR18500

Savannah River Operations Office

Aiken, South Carolina 


\section{DECISION SUMMARY TABLE OF CONTENTS}

\begin{tabular}{|c|c|}
\hline Section & $\begin{array}{cc} & \text { Page }\end{array}$ \\
\hline I. & Site Operable Unit Name, Location, and Description \\
\hline II. & Operable Unit History and Compliance History.......................... \\
\hline III. & Highlights of Community Participation.... \\
\hline IV. & 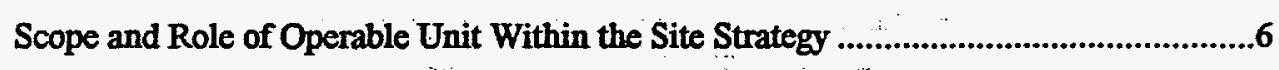 \\
\hline V. & Summary of Operable Unit Characteristics... \\
\hline VI. & Summary of Operable Unit Risks....... \\
\hline VII. & Description of the Considered Alternatives \\
\hline VIII. & Summary of Comparative Analysis of the Alternatives..............................................18 \\
\hline $\mathbf{I X}$. & The Selected Remedy.......... \\
\hline $\mathbf{X}$ & 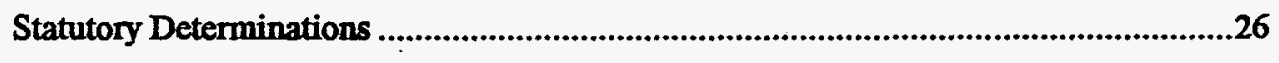 \\
\hline XI. & Explanation of Significant Changes............ \\
\hline XII. & Responsiveness Summary .... \\
\hline KIII. & 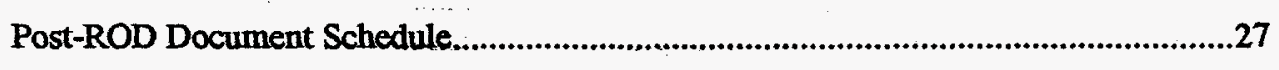 \\
\hline IV. & 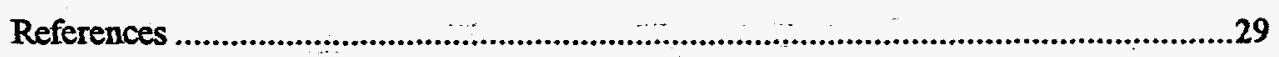 \\
\hline
\end{tabular}

\section{List of Fipures}

Figure 1. Location of the D-Area Burning/Rubble Pits in relation to major facilities at the Savannah River Site .2

Figure 2. Topography of the D-Area Burning/Rubble Pits and surrounding area....................................3

Figure 3. Topography and Water Table Potentiometric Map of the D-Area Burning/Rubble Pits .............4

Figure 4. Schedule for the Corrective Measures Implementation/Remedial Action Report

\section{List of Tables}

Table 1. Summary of Carcinogenic Risk and Noncarcinogenic Hazards for Current

On-Site Visitors at the D-Area Burning/Rubble Pits

Table 2. Summary of Carcinogenic Risk and Noncarcinogenic Hazards for Future On-Site Workers at the D-Area Burning/Rubble Pits.

Table 3. Summary of Carcinogenic Risk and Noncarcinogenic Hazards for Future On-Site Resident Adults and Children at the D-Area Burning/Rubble Pits.

Table 4. Summary of the Evaluation of Alternative 1 No Action under the Nine CERCLA Criteria 


\section{DECISION SUMMARY \\ TABLE OF CONTENTS (cont'd)}

Table 5. Summary of the Evaluation of Alternative 2 Institutional Controls under the Nine CERCLA Criteria.

Table 6. Summary of the Evaluation of Aiternative 3 Native Soil Cover (4') under the Nine CERCLA Criteria.

Table 7. Summary of the Evaluation of Alternative 4 Thermal Desorption/Incineration under the Nine CERCIA Criteria.

Table 8. Summary of the Evaluation of Alternative 5 Offsite Soil Disposal under the Nine CERCLA Criteria

\section{Appendix}

A. Re:sponsiveness Summary. 


\section{Site and Operable Unit Name, Location, and Description .........}

The Savannah River Site (SRS) occupies approximately 310 square miles of land adjacent to the Savannah River, principally in Aiken and Barnwell counties of westem South Carolina. SRS is a secured U.S. Government facility with no permanent residents. SRS is located approximately 25 miles southeast of Augusta, Georgia and 20 miles south of Aiken, South Carolina.

SRS is owned by the U.S. Department of Energy (DOE). Management and operating services are provided by Westinghouse Savannah River Company (WSRC). SRS has historically produced tritium, plutonium, and other special nuclear materials for national defense and the space program. Chemical and radioactive wastes are byproducts of nuclear material production processes.

The Federal Facility Agreement (FFA) lists the DArea Eurning/Rubble Pits (DBRP), 431-D and 431-1D, as a Resource Conservation and Recovery Act/Comprehensive Environmental Responsie, Compensation and Liability Act (RCRA/CERCLA) unit requiring further evaluation using an investigation/assessment process that integrates and combines the RCRA Facility Investigation (RFI) process with the CERCLA Remedial Investigation (RI) to determine the actual or potential impact to human health and the environment.

The DERP are located in the western part of the SRS in Barnwell County, approximately 2600 feet west of D Area and 1.6 miles west of State Highway 125 (Figure 1). The topography of the area is 19at and the surface of the DBRP is at.an elevation of 130 feet above mean sea level and 45 feet above the Savannah River (Figure 2). The water table is approximately 10 feet below ground surface in the area of the DBRP (Figure 3). Surface drainage is to the west-southwest toward a nearby ephemeral tributary. of the Savannith River.

The twi) contiguous waste pits are designated as 431-D and 431-1D and cover a total area of 0.54 acre. Approximate dimensions of 431-D are 257 feet by 46 feet by 10 feet, and the dimensions of 431-1D are 229 feet by 36 feet by 10 feet. The two pits are separated by a 15-foot wide berm of undisturbed soil. The total planar area of the DBRP is assumed to be 257. feet by 97 feet $(24,929$ $\mathrm{ft}^{2}$ ). The pits have been backfilled with soil and vegetation has been established on the resulting surface. The pit cover is raised above it the surrounding terrain, which is essentially level; to

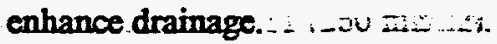

\section{Operable Unit History and Compliance History}

Operable Unit History

Between 1951 and 1973, burning pits were used at SRS to burn a variety of hazardous and nonhazardous waste. The chemical composition and volumes of the disposed waste are unknown. Combustible materials, which were bumed monthly, included paper, plastics, wood, rubber, rags, cardboard, oil, degreasers, and spent organic solvents. No known or suspected radioactive materials were allowed in the burning pits.

Burning of waste in the SRS pits was. discontinued by October 1973. A layer of soil was then placed over the residue in the pits and they were subsequently used as rubble pits. Materials allowed in the rubble pits generally included concrete, bricks, tile, asphalt, plastic, metal, empty drums, wood products, and rubber. When the pits were filled to capacity in 1983 or were no longer needed, a 1 to 3 foot layer of clayey soil was placed over the contents and the surface was compacted and mounded above the surrounding terrain, which is essentially: level, to enhance drainage...... Vegetation was established to reduce erosion.

\section{Compliance History}

At SRS, waste materials are managed which are regulated : under $=R C R A ;$ a . comprehensive: law requiring responsible management: of hazardous waste. Certain SRS activities have required Federal : operating or post-closure permits under RCRA. SRS received a hazardous waste permit from the South Carolina Department of Health:and Environmental Control (SCDHEC) on September

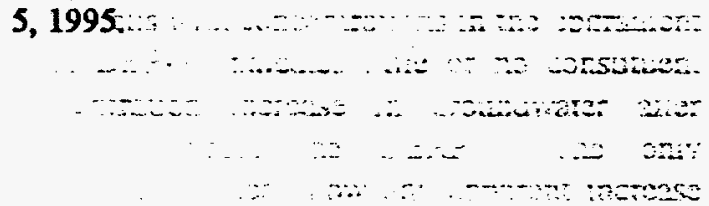


Figure 1. Location of the D-Area Burning/Rubble Pits in relation to major facilities at the Savannah River Site.

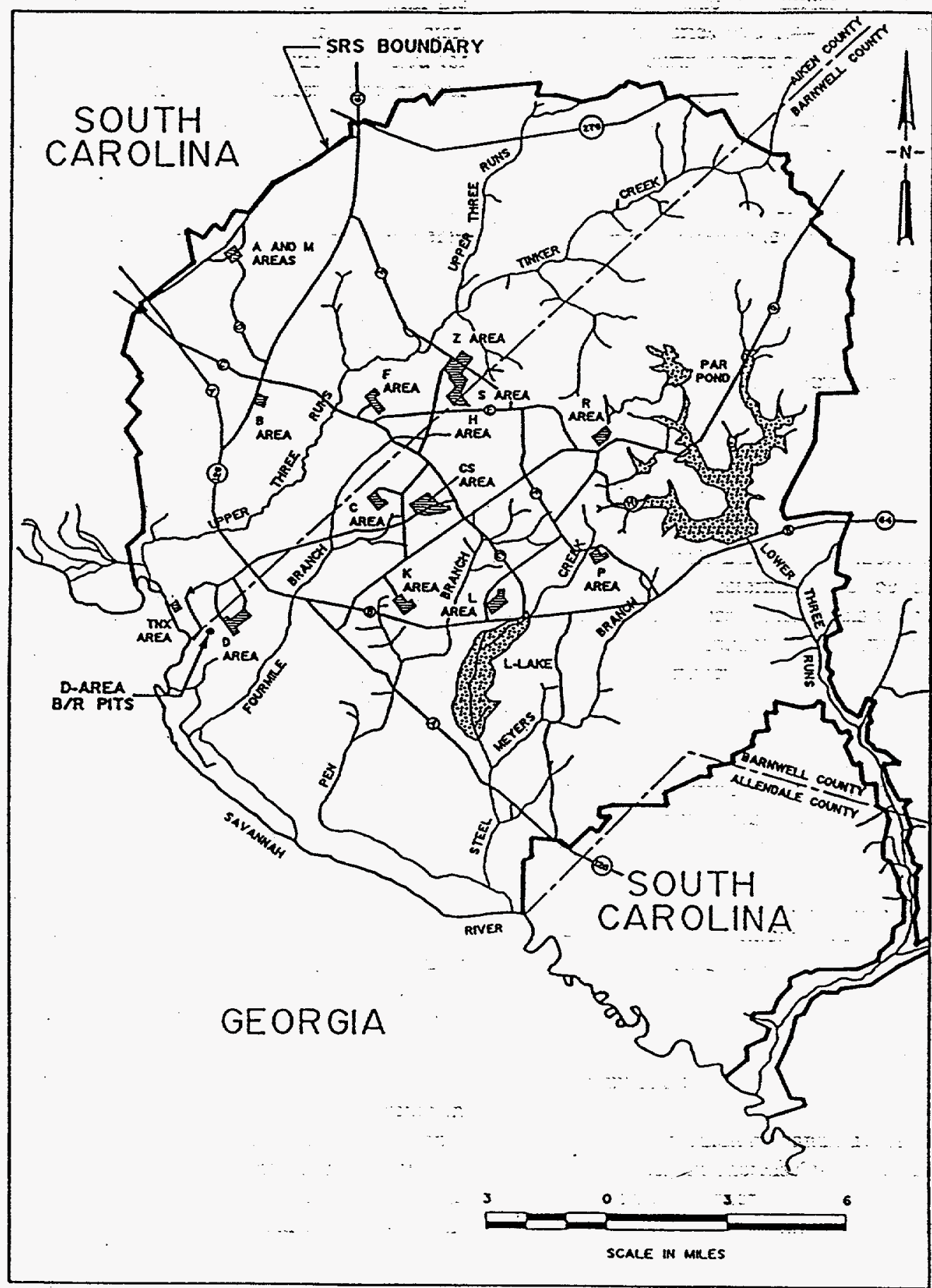

$$
\begin{aligned}
& -\quad \quad \cdots \\
& =\ldots \\
& =\ldots
\end{aligned}
$$


Figure 2. Topography of the D-Area Burning/Rubble Pits and surrounding area.

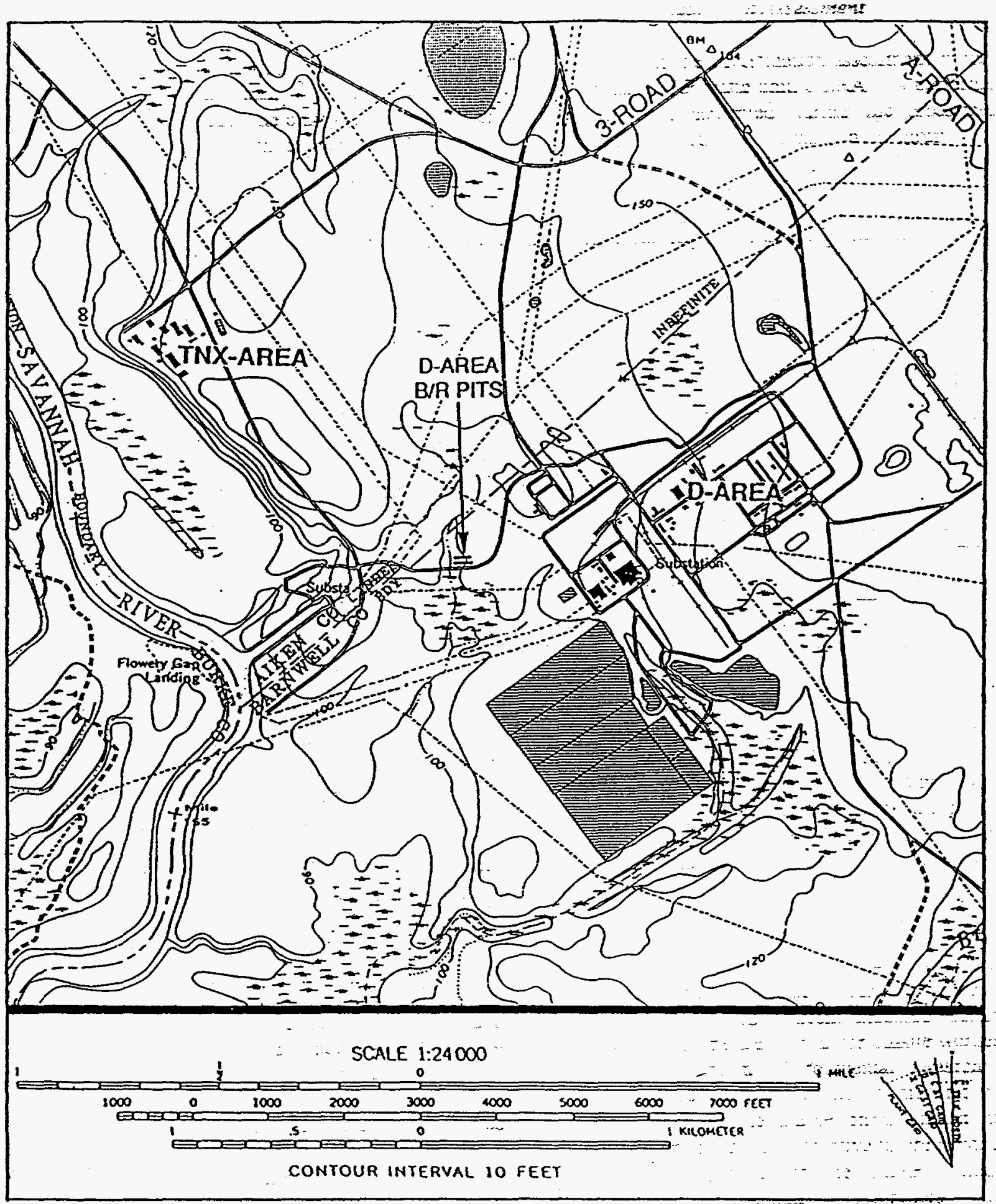

Modified from DPST-87-667. E.t. du Pont de Nemours and Company. 1987. 
Figure 3. Topography and Water Table Potentiometric Map of the D-Area Burning/Rubble Pits.
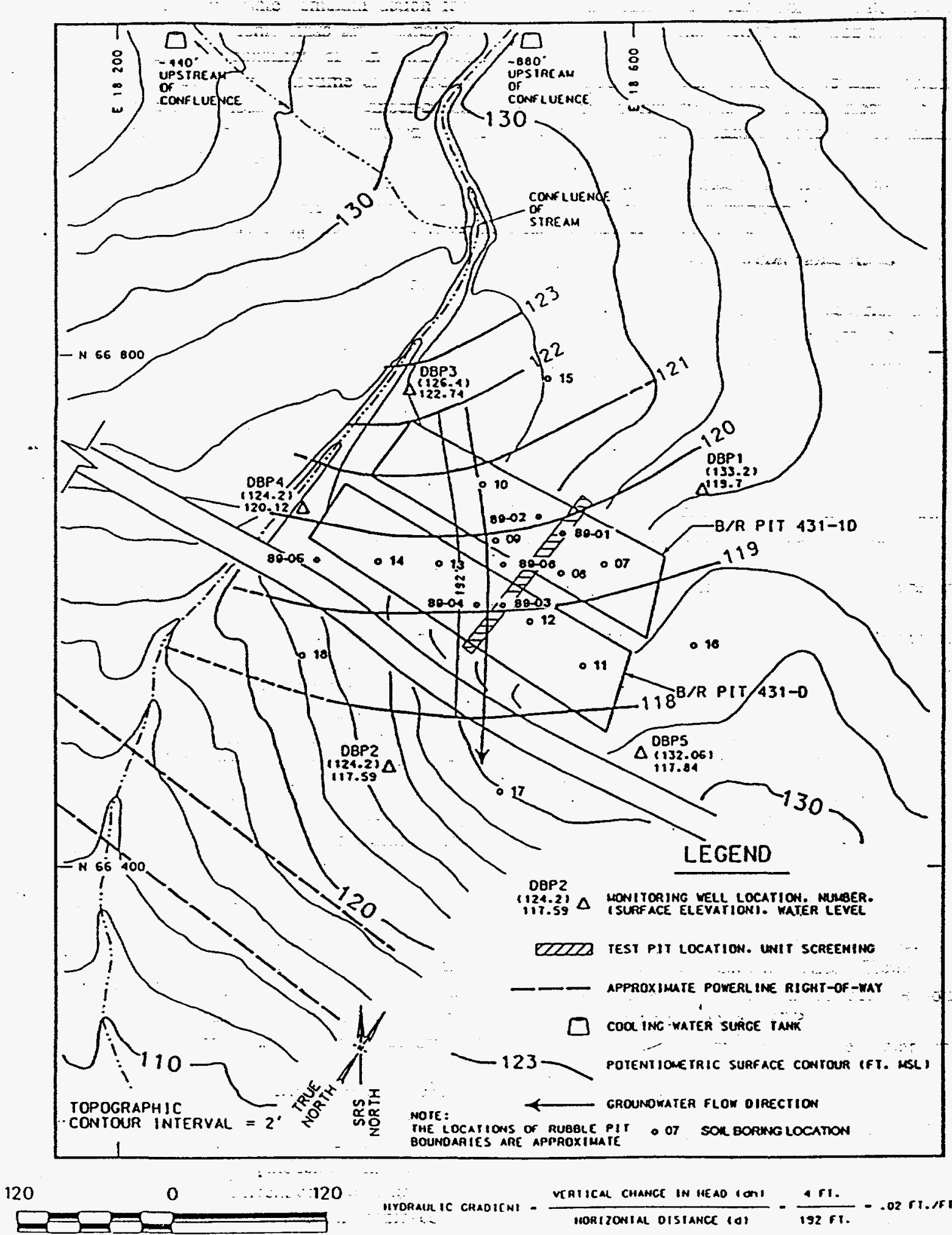

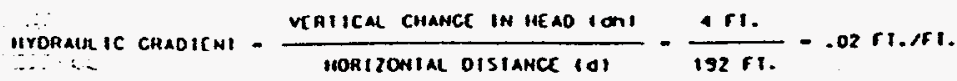

SCALE IN FECT 
Part V of the permit mandates that SRS establish and implement an RFI Program to fulfill the requirements specified in Section 3004(u) of the Federal permit.

On December 21, 1989, SRS was included on the National Priorities List (NPL). This inclusion created a need to integrate the established RFI Program with CERCLA requirements to provide for a focused environmental program. In accordance with Section 120 of CERCLA, DOE has negotiated a Federal Facility Agreement (FFA, 1993) with U. S. Environmental Protection Agency (EPA) and SCDHEC to coordinate remedial activities at $S R S$ into one comprehensive strategy which fulfills these dual regulatory requirements.

\section{Highlights of Community Participation}

Both RCRA and CERCLA require that the public be given an opportunity to review and comment on the draft permit modification and proposed remedial alternative. Public participation requirements are listed in South Carolina Hazardous Waste Management Regulation (SCHWMR) R61-79.124 and Sections 113 and 117 of CERCLA. These requirements include establishment of an Administrative Record File that documents the investigation and selection of the remedial alternatives for addressing the DBRP soils and groundwater. The Administrative Record File must be established at or near the facility at issue. The SRS Public Involvement Plan (DOE, 1994) is designed to facilitate public involvement in the decision-making process for permitting, closure, and the selection of remedial alternatives. The SRS Public Involvement Plan addresses the requirements of RCRA, CERCLA, and the National Environmental Policy Act, 1969 (NEPA). SCHWMR R.61-79.124 and Section 117(a) of CERCLA, as amended, require the advertisement of the draft permit modification and notice of any proposed remedial action and provide the public an opportunity to participate in the selection of the remedial action. The Statement of Basis/Proposed Plan for the D-Area Burning/Rubble Pits (WSRC, 1996c), which is part of the Administrative Record File, highlights key aspects of the investigation and identifies the preferred action for addressing the DBRP.

The FFA Administrative Record File, which contains the information pertaining to the selection of the response action, is available at the EPA office and at the following locations:

U.S. Department of Energy

Public Reading Room

Gregg-Graniteville Library

University of South Carolina-Aiken

171 University Parkway

Aiken, South Carolina 29801

(803) 641-3465

-Thomas Cooper Library

Government Documents Department

University of South Carolina

Columbia, South Carolina 29208

(803) 777-4866

Reese Library

Augusta State University

2500 Walton Way

Augusta, Georgia 30910

(706) 737-1744

Asa H. Gordon Library

Savannah State University

Tompkins Road

Savannah, Georgia 31404

(912) 356-2183

The public was notified of the public comment period through mailings of the SRS Environmental Bulletin, a newsletter sent to approximately 3500 citizens in South Carolina and Georgia, through notices in the Aiken Standard, the Allendale Citizen Leader, the Augusta Chronicle, the Barnwell People-Sentinel, and The State newspapers. The public comment period was also announced on local radio stations.

The 45-day public comment period began on September 17, 1996 and ended on October 31, 1996. A public comment meeting was held on October 15, 1996. A Responsiveness Summary was prepared to address comments received during the public comment period. The Responsiveness Summary is available with the final RCRA permit and is also provided in Appendix A of this Record of Decision (ROD). 


\section{Scope and Role of Operable Unit Within the Site Strategy}

The overall strategy for addressing the DBRP was to:

1) characterize the waste unit delineating the nature and extent of contamination and identifying the media of concern (WSRC, 1994 and WSRC, 1995b);

2) perform a baseline risk assessment to evaluate media of concern, constituents of concern (COCs), exposure pathways, and characterize potential risks (WSRC, 1995a);

3) evaluate applicable technologies and isolate a preferred technology to remediate the waste site: as needed (WSRC, 1996b and WSRC, 1996c); and

4) perform a final action to remediate the identified media of concern to the remedial action objectives.

The DI3RP is an operable unit located within the Savannah River Floodplain Swamp Watershed. Several source control and groundwater operable units nithin this watershed will be evaluated to determine impacts, if any, to associated streams and wetiands. SRS will manage all source control and groundwater operable units to minimize impact to the watershed. Based on characterization and risk assessment information, the DHRP does not significantly. impact the watershed. Upon disposition of all source control and groundwater operable units within this watershed, a final, comprehensive evaluation of the watershed will be conducted to determine whethe: any additional actions are necessary. The groundwater at the DBRP was investigated during the RFI/RI conducted in 1993. The Baseline Risk Assessrnent (BRA) (WSRC, 1995a) found no risks exceeding $1.0 \times 10^{-6}$ for ingestion of the DBRP soil by future industrial workers, but calculated a risk of $3.0 \times 10^{-4}$ for ingestion of groundwater by future industrial workers. Additional groundwater monitoring of the groundwater for modeled risk and hazard drivers at the DBRP will be conducted and reported in the five-year $R O D$ reviews.

\section{Summary of Operable Unit Characteristics}

The SF:S burning/rubble pits were excavated in 1951, during the construction of most of the major facilities at the Savannah River Plant. The DBRP received waste materials produced during construction of D-Area facilities. The chemical composition and volumes of the disposed waste are unknown. During the operation of the burning/rubble pits, combustible materials (including paper, plastics, wood, rubber, rags, cardboard, oil, degreasers, and spent organic solvents) were burned monthly, as was the practice at that time, for volume reduction. This practice would have eliminated many of the combustible organic materials while creating combustion by-products. No known or suspected radioactive materials were disposed in the burning pits.

Open burning of waste material was discontinued at SRS in 1973. At that time, the waste residue was covered with soil and the pits were used as rubble pits. Materials allowed in the rubble pits included concrete, bricks, tile, asphalt, plastic, metal, empty drums, wood products, and rubber. When the pits were filled to capacity about 1983, a 1 to 3 foot layer of clayey soil was placed over the contents and the surface was compacted, mounded, and seeded.

\section{Media Assessment}

The Data Summary Report (WSRC, 1994), BRA (WSRC, 1995a), RFI/RI Report (WSRC, 1995b), and Corrective Measures Study/Focused Feasibility Study (WSRC, 1996b) contain detailed analytical data for all of the environmental media samples taken in the characterization of the DBRP. These documents are available in the Administrative Record (See Section III).

\section{Soils}

Analytical data indicate that little or no contamination of the soil outside of the DBRP has occurred. Figure 3 shows the sample locations for the Phase I characterization in 1989 and the Phase II characterization in 1993. The 1989 program included two locations in each pit, one in the berm between the pits, and one directly down gradient of the pits. The 1993 program consistod of four soil borings in each pit and four borings around the pits.

In the BRA, the analytical data from the 1993 soil samples were divided into two groups:

- surface soils, 0.0 to 2.0 feet (primary direct contact exposure interval for soils) and 
- subsurface soils, 0.0 to 4.0 feet (potential exposure interval for future scenarios where excavation may occur).

The BRA identified the following constituents of concern:

arsenic,
benzo(a)pyrene,
chromium,
manganese,
octachlorodibenzo-p-dioxin,
PCB-1260, and
total alpha emitting radium.

Dieldrin was identified as a modeled-DBRPsoils-to-groundwater ingestion risk driver to future rasidents, $81 \%$ of $8 \times 10^{-4}$ in Revision 0 of the BRA. Dieldrin was only detected two times out of 45 soil samples collected in the DBRP. The maximum value reported was $\mathbf{0 . 0 1 6 5}$ $\mathrm{mg} / \mathrm{Kg}$ in the 4 to 6 foot interval of boring 11, the " $\mathrm{J}$ " qualifier indicates that the analyte was recognized below detection limits and the value was estimated. The risk contribution of dieldrin was recvaluated in the BRA, Revision 1 and dieldrin was eliminated as a risk driver based on its high uncertainty of detection and low number of occurrences.

Two tirnes the mean background value for a constituent was used in screening that constituent for consideration as a constituent of potential concern. The mean background value for arsenic at the DBRP is $2.3 \mathrm{mg} / \mathrm{kg}$. In the 0-2 foot inturval of the DBRP, arsenic only excoeds 2 times mean background $(4.6 \mathrm{mg} / \mathrm{kg}$, parts per million) at one location, boring $7(7.6 \mathrm{mg} / \mathrm{kg})$. The levels of arsenic detected are consistent with the levels found throughout SRS. Arsenic may be naturally occurring, added to the soils as a pesticide, or a constituent of waste materials disposed in the DBRP. Arsenic in the soil at SRS is believed to be primarily the residue of pre-SRS agricultural pesticide application. The occurrence of arsenic will be evaluated on a sitewide scale in the forthcoming SRS background soils study report.

In the near-surface soil at the DBRP, chromium only exceeded 2 times mean background (80.8 $\mathrm{mg} / \mathrm{kg}$ ) in boring 12 (339 $\mathrm{mg} / \mathrm{kg}$ ). The chromium present in the DBRP is believed to be predominantly CrIII (chromium in the +3 valence state) which is much less mobile and toxic than the CrVI (chromium+6) assumed in the BRA evaluation. CrVI is thermodynamically unstable in soils in the region including SRS and is rapidly reduced to CrIII. Manganese only exceeded 2 times mean background (242 $\mathrm{mg} / \mathrm{kg}$ ) in the near-surface interval in boring 11 (260 mg/kg).

Benzo(a)pyrene (BaP) did not exceed detection limits in the 0-2 foot interval at the DBRP. Octachlorodibenzo-p-dioxin (OCDD), which -.. comprised only- $9 \%$ of the risk via soil ingestion for future on-site workers, was detected at low concentrations in all of the shallow soil samples. Dioxins are common products of incomplete combustion. Polychlorinated Biphenyl-1260 (PCB-1260) was identified in only one location, soil boring 12; the maximum concentration of PCB-1260, $3.39 \mathrm{mg} / \mathrm{kg}$, was found in the $0.5-2.0$ foot interval. Total alpha emitting radium was only detected in the 0-2 foot interval (1.2 pCi/g) in boring $7 ; 2$ times mean background was 2.49 pCi/g.

Based on the fact that all the soil analytes passed either the simple site-specific or detailed sitespecific method of screening, there is little or no chance for the residual waste at the DBRP to be a source of future contamination. The remaining soil contaminants pose little, if any threat for future contamination.

\section{Groundwoter}

Groundwater monitoring data indicate that no significant release of hazardous substances to groundwater from the DBRP has occurred. However, risk evaluation indicates a groundwater ingestion risk of $3.0 \times 10^{-4}$ for future workers and $1.0 \times 10^{-3}$ for future residents due to arsenic (discussed later in this section). There are 5 monitoring wells in the DBP (DArea Burning Pit) well series: DBP-1, -2, -3 (installed in September 1983), DBP- 4 (installed in June 1984), and DBP-5 (installed in June 1993). Figure 3 shows the locations of the monitoring wells comprising the DBP network and the potentiometric water table map.

Comparison of constituent concentrations, from 1984 through 1992 in the four downgradient DBP wells with concentrations in the upgradient well, DBP-3, indicates little or no constituent concentration increase in groundwater after flowing beneath the DBRP. The only constituents which show any apparent increase 
are iron, manganese, lead, sulfate, and possibly gross alpha and total radium. Iron, manganese, and sulfate are covered by the Secondary Drinking Water Standards which deal with the aesthetic properties of public drinking water. The RCRA groundwater protection standand for lead is $0.05 \mathrm{mg} / \mathrm{L}$. The highest value of lead reported for the period of interest was 0.013 mg/L.

The measured groundwater risk drivers under the future resident scenario are: $\cdots$ arsenic (dermal, $3 \times 10^{-6}$ and ingestion, $1 \times 10^{-3}$ ); dichloromethane (inhalation, $2 \times 10^{-8}$ ); $\operatorname{Ra}-226$ and $\mathrm{Ra}-228$ (ingestion, $2 \times 10^{-5}$ ); and tritium (inhalation, $3 \times 10^{-9}$ ). The modeled-DBRP-soils to groundwater risk drivers are octachlorodibenzo-p-dioxin (OCDD) and heptachlorodibenzo-p-dioxin (HpCDD) (dermal, $1 \times 10^{-4}$; polyaromatic hydrocarbons (PAHs) and 1,1,2-trichloroethane (1,1,2-TCA) (ingestion, $\left.2 \times 10^{-4}\right) ; 1,2$-dichloroethane (1,2DCA), 1,1,2-TCA, and chloroform (inhalation, $3 \times 10^{-5}$ ); and tritium (ingestion, $2 \times 10^{-5}$ and inhalation, $3 \times 10^{-5}$ ). The measured groundwater hazard drivers are: imanganese (dermal, 1.0); arsenic and manganese (ingestion, 50.0); and toluene (inhalation, 0.005). The modeled-DBRP-soil-togroundwater hazard drivers are: OCDD and HpCDD (dermal, 5.0); acetone and naphthalene (ingestion, 20.0); and carbon disulfide (inhalation, 0.3). Many of these exposure scenarios are well below the $1 \times 10^{-6}$ risk and 1.0 hazard levels.

Arsenic was the sole nonradioactive contributor to risk under the measured groundwater ingestion pathway in the BRA. The risk to the future on-unit worker was $3.0 \times 10^{-4}$; to the future on-unit resident the risk was $1.0 \times 10^{-3}$. The maximum contaminant level for arsenic in drinking water is $0.05 \mathrm{mg} / \mathrm{L}$. Arsenic was only detected twice in the DBP monitoring network; the higher value in the December 1993 sample from well DBP-5 was reported as $0.044 \mathrm{mg} / \mathrm{L}$. The following quarter when the well was resampled, arsenic was reported below detection limits of $0.002 \mathrm{mg} / \mathrm{L}$. Therefore the risks attributed to this single arsenic value are believed to be exaggerated.

Manganese is covered by the secondary maximum contaminant level of $0.05 \mathrm{mg} / \mathrm{L}$. This contaminant level addresses the aesthetic properties of public drinking water rather than dealing with health-based concerns. The maximum value of manganese reported in the DBP well series was $1.44 \mathrm{mg} / \mathrm{L}$ from well DBP 2 in the fourth quarter of 1993.

Dichloromethane (methylene chloride), a common laboratory artifact; was only reported in three soil samples in a total of 55 samples collected from the DBRP with a maximum of V0.06 $\mathrm{mg} / \mathrm{Kg}$ (boring 7 at a depth of 4.0-6.0 feet). The " ${ }^{m}$ qualifier indicates that the analyte was also detected in the associated method blank, indicating laboratory contamination. The risk attributed to dichloromethane via the groundwater inhalation pathway by future residents was $2 \times 10^{*}$, well below $1 \times 10^{-6}$. Dichloromethane was detected in the groundwater in excess of the $0.005 \mathrm{mg} / \mathrm{L}$ maximum contaminant level four times since January 1993, two of these exceedances were in upgradient well DBP 3. Dichloromethane was evaluated and determined to be a laboratory artifact. Likewise, acetone has been detected in up- and downgradient wells and is a common laboratory artifact. -.......

Gross alpha and total radium were the only radioactive constituents in the Unit Assessment samples (covering three quarters in 1993) for which primary maximum contaminant levels may have been exceeded. The maximum contaminant level (MCL) for gross alpha is 15 pCin, this level may have been exceeded in the December 1993 sample from well DBP-2 (15 $\mathrm{pCi} / \mathrm{L} \pm 0.21 \mathrm{pCi} / \mathrm{L})$. This gross alpha anomaly occurred only once in a single well that had previously contained no detectable gross alpha and may be due to field or laboratory contamination.

The MCL (regulatory standard) for total radium is $5 \mathrm{pCi} / \mathrm{L}$; an increase to $20 \mathrm{pCi} / \mathrm{L}$ is being considered - under proposed regulations (56FR33050). Total radium in the groundwater has only exceeded $5 \mathrm{pCi} / \mathrm{L}$ once since monitoring began at the DBRP. This exceedance occurred in the sample collected from well DBP-2 in December 1993 (the same sample which yielded the gross alpha anomaly); Ra-226 was $4.8 \mathrm{pCi} / \mathrm{L}$ and $\mathrm{Ra}-228$ was 3.5 $\mathrm{pCi} /$. The relationship of the gross alpha and Ra-226/228 anomalies in the same sample 
suggests that these anomalies could be due to problems with laboratory or field sampling techniques.

During evaluation performed for the BRA, the assumption was made that all the radium present was Ra-226, the only radium species for which slope factors have been determined and the most toxic radium species. This assumption contributed to an exaggeration of the risk attributed to radium. The ingestion of radium in the groundwater pathway risks was evaluated at $6.0 \times 10^{-6}$ for future workers and $2.0 \times 10^{-5}$ for future residents.

Tritium was recognized as a risk driver in the modeled-DBRP-soil-to-groundwater exposure pathway as discussed in the preceding paragraphs. Tritium only exceeded the two times mean background screening level (5.26 $\mathrm{pCi} / \mathrm{g}$ ) in the DBRP soils seven times in $\mathbf{4 9}$ soil samples, the maximum value reported was 13.5 $\mathrm{pCi} / \mathrm{g}$ from the 2 to 4 foot interval in boring 8 . The maximum contaminant level for tritium is $20,000 \mathrm{pCi} / \mathrm{L}$, the highest value of tritium reported from the groundwater was only $\mathbf{3 4 0 0}$ $\mathrm{pCi} / \mathrm{L}, 17 \%$ of the MCL. The maximum modeled-soil-to-groundwater concentration was $11,500 \mathrm{pCi} / \mathrm{L}$.

The PAHs, HpCDD, OCDD, 1,1,2-TCA, 1,2DCA, carbon disulfide, and chloroform have not been detected in groundwater. These constituents have very low solubilities in aqueous systems and tend to be strongly adsorbed to clays and humates in the soil; they are not readily transferred from soil to groundwater. The modeling in the BRA is conservative in that it assumes that the contaminant is present at its maximum detected concentration throughout the waste body and that the contaminant does not suffer degradation or depletion, thus the modeled-DBRP-soil-togroundwater risks are exaggerated.

Under current land use (and recommended institutional controls)' the on-site visitor is supplied with drinking water from the SRS drinking water supply system. Under SRS institutional control, the local groundwater at the DBRP is not used for drinking or hygienic purposes.

\section{VL Summary of Operable Unit Risks}

\section{Human Health Risk Assessment}

As part of the investigation/assessment process for the DBRP waste unit, a BRA was performed using :-data generated during the assessment phase. Detailed information-regarding the development of constituents of potential concern (COPCs), the fate and transport of contaminants, and the risk assessment can be found in the BRA (WSRC, 1995a) and the RFI/RI Report for the -D-Area Burning/Rubble Pits (431-D and 431-1D) (U). (WSRE, 1995b).

COPCs are site- and media-specific, man-made and naturally occurring, inorganic and organic chemicals, pesticides, and radionuclides detected at a unit under investigation. These constituents are potentially site-related and data treating their distribution and concentration are of sufficient quality for use in the risk assessment. The process of designating the COPCs was based on consideration of ... background concentrations, frequency of detection, the relative toxic potential of the chemicals, and chemical nutrient status.

Constituents of concern (COCs) are isolated from the list of COPCs by calculating carcinogenic (cancer-causing) risks and noncarcinogenic hazard indices. $A . C O C$ contributes significantly to a pathway that contributes to either. a cumulative site carcinogenic risk greater than $1.0 \times 10^{-6}$ or a hazard index greater than 1.0.

An exposure assessment was performed to provide an indication of the potential exposures which could occur based on the chemical concentrations detected during sampling activities. The only current exposure scenario identified for the DBRP was for on-site workers, who may perform environmental research - or maintenance activities (such as mowing and inspections) on the DBRP on a limited and intermittent basis. Conservative future exposure scenarios identified for the DBRP included future environmental researchers and maintenance workers and future resident adults and children ... The reasonable maximum exposure concentration value was used as the exposure point concentration.........:...... 
Per EPA guidance, the carcinogenic risks and noncarcinogenic hazards must be calculated to determine the appropriate remedial action for a waste unit. Carcinogenic risks are estimated as the incremental probability of an individual developing cancer over a lifetime as a result of pathway-specific exposure to cancer-causing contaminants. These risks are expressed as the increased likelihood that an exposed individual will develop cancer during his lifetime (70 years) because of a 30-year (chronic) exposure to the contaminants at a given waste site.

Cancer risks are related to the EPA target risk range of one in ten thousand $\left(1.0 \times 10^{-7}\right)$ to one in one million $\left(1.0 \times 10^{-6}\right)$ for incremental cancer risk at National Priorities List sites.

Remedy selection, addressing significant risks and/or principal threat source material, was completed in a comprehensive Corrective Measures Study/Feasibility Study (CMS/FS). Alternatives that are permanent and/or employ treatment as a principal element of the remedy are necessary for inclusion in the CMS/FS.

Non-carcinogenic effects are also evaluated to identify a level at which there may be concern for potential health effects other than cancer. The hazard quotient, which is the ratio of the exposure dose to the reference dose, is calculated for each contaminant. Hazard quotients are summed for each exposure pathway to determine the specific hazard index (HI) for each exposure scenario. If the hazard index exceeds unity (1.0), there is concern that adverse health effects might occur.

Exposure risks and hazards for the three land use scenarios are presented in Tables 1 through 3. The future residential scenario includes homegrown produce as an exposure point, which is not considered under the current onunit visitor or future industrial worker scenarios.

\section{Current Land Use - Noncarcinogenic Hazards}

Under the current land use scenario, human health risks and noncarcinogenic hazards were characterized for the current on-unit visitor. An on-unit visitor is described as an employee of SRS who works at the DBRP for short periods on an infrequent basis, (i.e., a few hours per month performing environmental sampling or maintenance activities). Current on-unit visitors are supplied with drinking water from the SRS drinking water supply system; the local groundwater is not used for drinking or hygiene.

The BRA (WSRC,-1995a) shows that potential adverse noncarcinogenic bealth effects are not likely to cocur, because none of the hazard indices exceeds a value of one. Table 1 contains a summary of noncarcinogenic hazards under the current land use scenario.

\section{Current Land Use - Carcinogenic Risks}

Under the current land use scenario, human health risks were characterized for the current on-unit visitor. Table 1 contains a summary of carcinogenic risks. All of the estimated nonradiological cancer risks were less than $1.0 \mathrm{x}$ $10^{-6}$, indicating that carcinogenic risk from the unit is not significant. Media evaluated include soil inside the DBRP, soil outside the DBRP, associated airborne soil particulates, and surface water and sediment in the stream/wetland.

All of the estimated radiological risks were less than $1.0 \times 10^{-6}$. Radiological risks were estimated for three exposure pathways: ingestion of soil inside the DBRP, inhalation of particulates from soil inside the DBRP, and ingestion of sediment.

\section{Future Land Use - Noncarcinogenic Hezards}

The HIs were less than one, indicating adverse noncarcinogenic effects are unlikely for the following pathways:

- direct exposure of on-unit workers to soils inside and outside the DBRP (Table 2)

- direct exposure of adult and child residents to soils inside and outside the DBRP (Table 3)

- direct exposure of child-only residents to soils inside and outside the DBRP

- exposure of a child to surface water and sediment 
Table 1. Summary of Carcinogenic Risk and Noncarcinogenic Hazards for Current On-Site Visitors at the D-Area Burning/Rubble Pits.
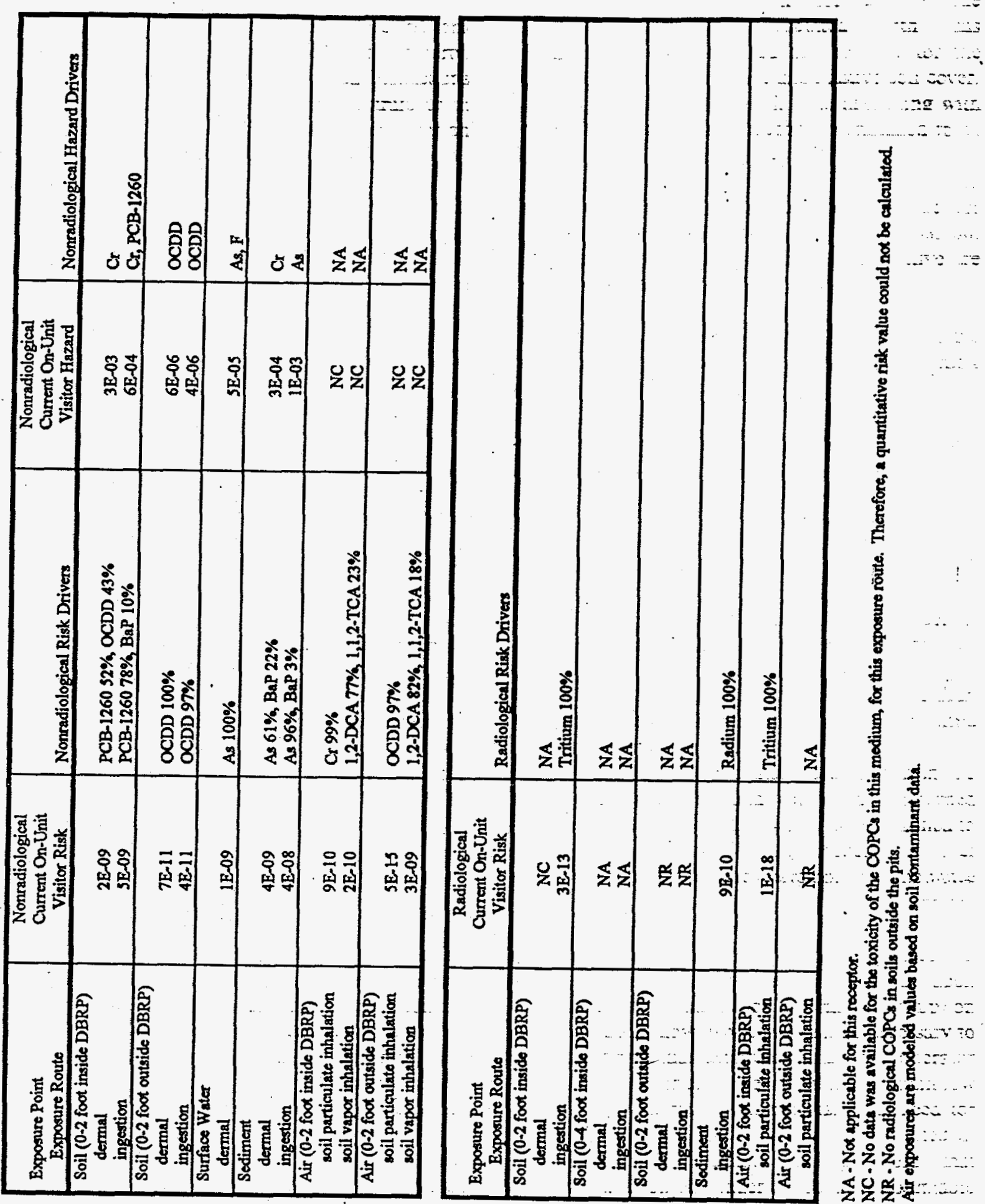


\begin{tabular}{|c|c|c|c|c|}
\hline $\begin{array}{l}\text { Exposure Point } \\
\text { Exposure Route }\end{array}$ & $\begin{array}{l}\text { Nonradiological } \\
\text { Future On-Unit } \\
\text { Worker Risk }\end{array}$ & Nonradiological Risk Drivers & $\begin{array}{l}\text { Nonradiological } \\
\text { Future On-Unit } \\
\text { Worker Hazard }\end{array}$ & Nonradiological Hazand Drivers \\
\hline $\begin{array}{l}\text { Soil ( } 0-2 \text { foot inside DBRP) } \\
\text { ingestion }\end{array}$ & 1E-06 & PCB-1260 78\%, BaP 10\%, OCDD 9\% & 3E-02 & Cr \\
\hline $\begin{array}{l}\text { Soil (0-4 foot inside DBRP) } \\
\text { ingestion }\end{array}$ & 1E-06 & PCB-1260 78\%, BaP 10\%, OCDD $9 \%$ & $3 \mathrm{E}-02$ & Cr \\
\hline $\begin{array}{l}\text { Soil ( } 0-2 \text { foot outside DBRP) } \\
\text { ingestion }\end{array}$ & 8E-09 & OCDD $97 \%$ & 1E-04 & OCDD \\
\hline $\begin{array}{l}\text { Oroundwater (measured) } \\
\text { ingertion }\end{array}$ & 3E-04. & As $100 \%$ & $6 \mathrm{E}+00$ & As, $\mathrm{Mn}$ \\
\hline $\begin{array}{l}\text { Groundwater (modeled) } \\
\text { ingestion }\end{array}$ & 4E-05 & PAH 55\%, 1,2-DCA 10\%, As 9\% & $2 E+\infty 0$ & Acetone \\
\hline $\begin{array}{l}\text { Air (0-2 foot inside DBRP } \\
\text { soil particulate inhalation }\end{array}$ & 4E-07 & Cr $100 \%$ & NC & NA \\
\hline $\begin{array}{l}\text { Air (0-4 foot inside DBRP) } \\
\text { soil particulate inhalation } \\
\text { soil vapor inhalation }\end{array}$ & $\begin{array}{l}6 \mathrm{E}-07 \\
4 \mathrm{E}-09 \\
\end{array}$ & $\begin{array}{l}\text { Cr } 100 \% \\
1,2-D C A 77 \%, 1,1,2 \text {-TCA } 23 \%\end{array}$ & $\begin{array}{l}\text { NC } \\
\text { NC }\end{array}$ & \begin{tabular}{l|c} 
& \\
NA & $\vdots$ \\
NA & $\vdots$
\end{tabular} \\
\hline $\begin{array}{l}\text { Air (0-2 foot outside DBRP) } \\
\text { soil particulate inhalation } \\
\text { soil vapor inhalation }\end{array}$ & $\begin{array}{l}1 \mathrm{E}-12 \\
1 \mathrm{E}-07\end{array}$ & $\begin{array}{l}\text { OCDD } 97 \% \\
1,2-D C A ~ 82 \%, 1,1,2-\text { TCA } 18 \%\end{array}$ & $\begin{array}{l}\text { NC } \\
\text { NC }\end{array}$ & $\begin{array}{l}\text { NA } \\
\text { NA }\end{array}$ \\
\hline
\end{tabular}

\begin{tabular}{|c|c|c|c|}
\hline $\begin{array}{l}\text { Exposure Point } \\
\text { Exposure Route }\end{array}$ & $\begin{array}{l}\text { Rediological } \\
\text { Future On-Unit } \\
\text { Worker Risk }\end{array}$ & Radiological Risk Drivers & \\
\hline $\begin{array}{l}\text { Soil (0-2 foot inside DBRP) } \\
\text { direct radiation } \\
\text { ingestion }\end{array}$ & $\begin{array}{c}N C \\
7 E_{-11}\end{array}$ & $\begin{array}{l}\text { NA } \\
\text { Tritium } 100 \%\end{array}$ & .. \\
\hline $\begin{array}{l}\text { Soil (0-4 foot inside DBRP) } \\
\text { direct radiation! } \\
\text { ingestion }\end{array}$ & $\begin{array}{c}\mathrm{NC} \\
7 \mathrm{E}-11\end{array}$ & $\begin{array}{l}\text { NA } \\
\text { Tritium 100\% }\end{array}$ & \\
\hline $\begin{array}{l}\text { Oroundwater (measured) } \\
\text { ingestion and inhalation }\end{array}$ & $6 \mathrm{E}-06$ & $R a-22655 \%, R a-22832 \%$ & \\
\hline $\begin{array}{l}\text { Groundwater (modeled) } \\
\text { ingestion and inhalation }\end{array}$ & SE-06 & Tritium $100 \%$ & \\
\hline $\begin{array}{l}\text { Air (0-2 foot inside DBRP) } \\
\text { soil particulate inhalation }\end{array}$ & $-3 \mathrm{E}_{-17}$ & Tritium 100\% & \\
\hline
\end{tabular}

NA - Not applicabla for this receptor.

NC. No data was avilable for the toxicity of the COPCs in this medium, for this oxposure route. Therefore, a quantitative risk value could not be calculated.

NR - No radiological COPCs in soils outside the pits.

Air exposures are modeled values based on soil contaminant data. 
Table 3. Summary of Carcinogenic Risk and Noncarcinogenic Hazards for Future On-Site Resident Adults and Children at the D-Area Burning/Rubble Pits.

\begin{tabular}{|c|c|c|c|c|c|c|c|c|c|c|c|c|c|}
\hline 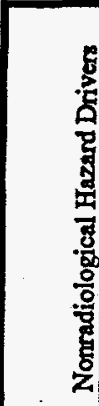 & 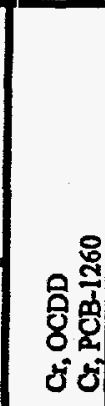 & 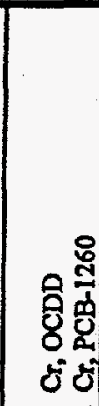 & 80 & 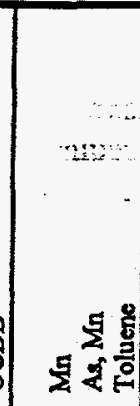 & 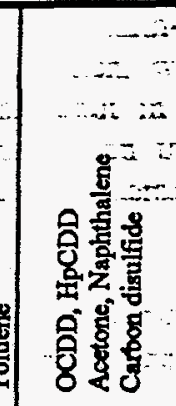 & 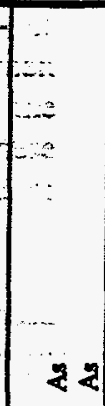 & 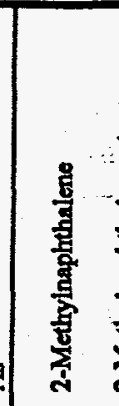 & 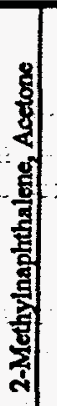 & 82 & $f=$ & $=-$ & $f$ & $\frac{2}{2}=0$ \\
\hline 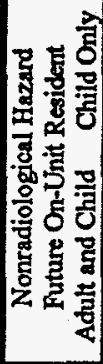 & 우유 & 可宮 & $\begin{array}{l}\text { 总总 } \\
\text { 品 }\end{array}$ & 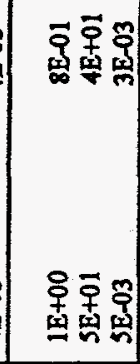 & 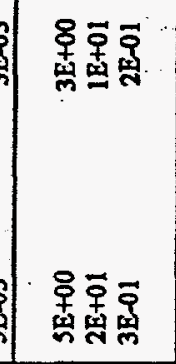 & 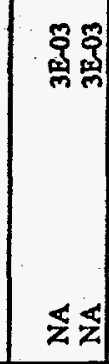 & § & $\begin{array}{l}5 \\
\vdots\end{array}$ & $\leq \leq \leq$ & 기 & $\underset{z}{0}$ & $U_{z}$ & \\
\hline 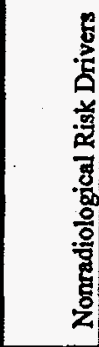 & 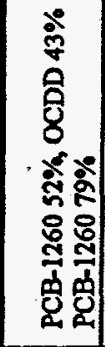 & 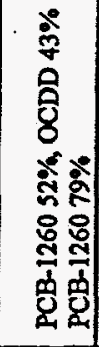 & 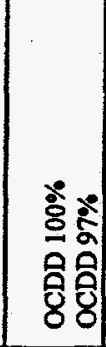 & 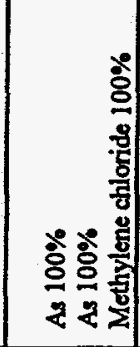 & 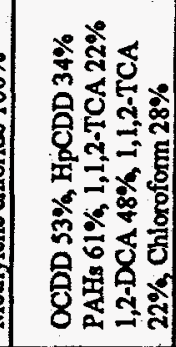 & 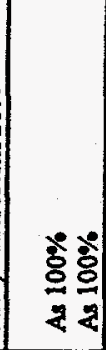 & 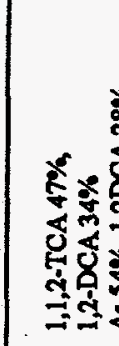 & 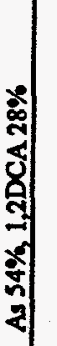 & 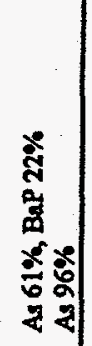 & 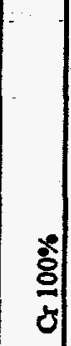 & 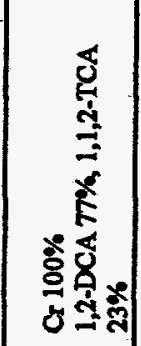 & 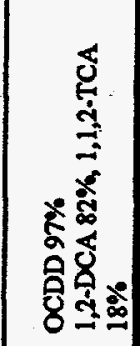 & , \\
\hline 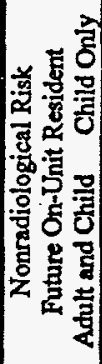 & \$口 & 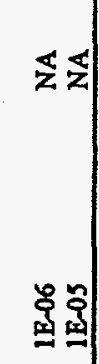 & $\begin{array}{l}\infty \\
\vdots \\
\vdots \\
\text { a }\end{array}$ & 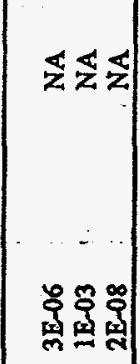 & 索高高 & $\begin{array}{l}\therefore \\
x \leq 1\end{array}$ & $\mathbb{z}$ & \$े & <女 & ڤे & \$े & 옹ำ & $\ldots$ \\
\hline 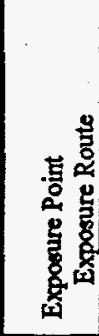 & 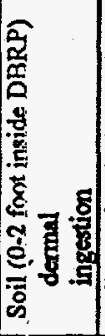 & 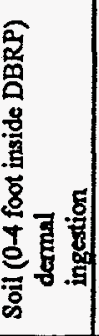 & 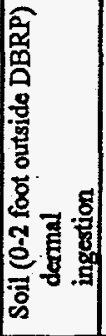 & 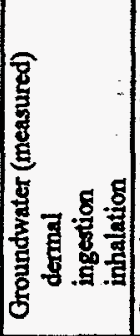 & 拿 & 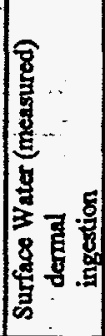 & 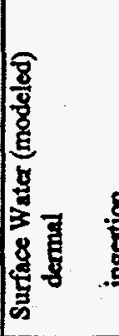 & & 表 & 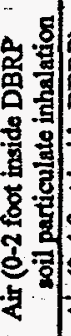 & 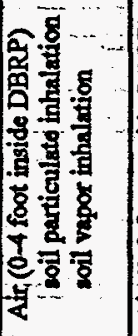 & 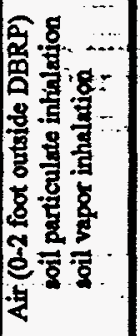 & 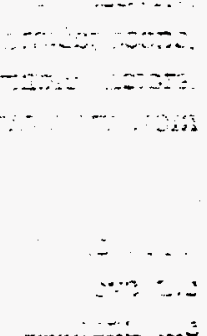 \\
\hline
\end{tabular}




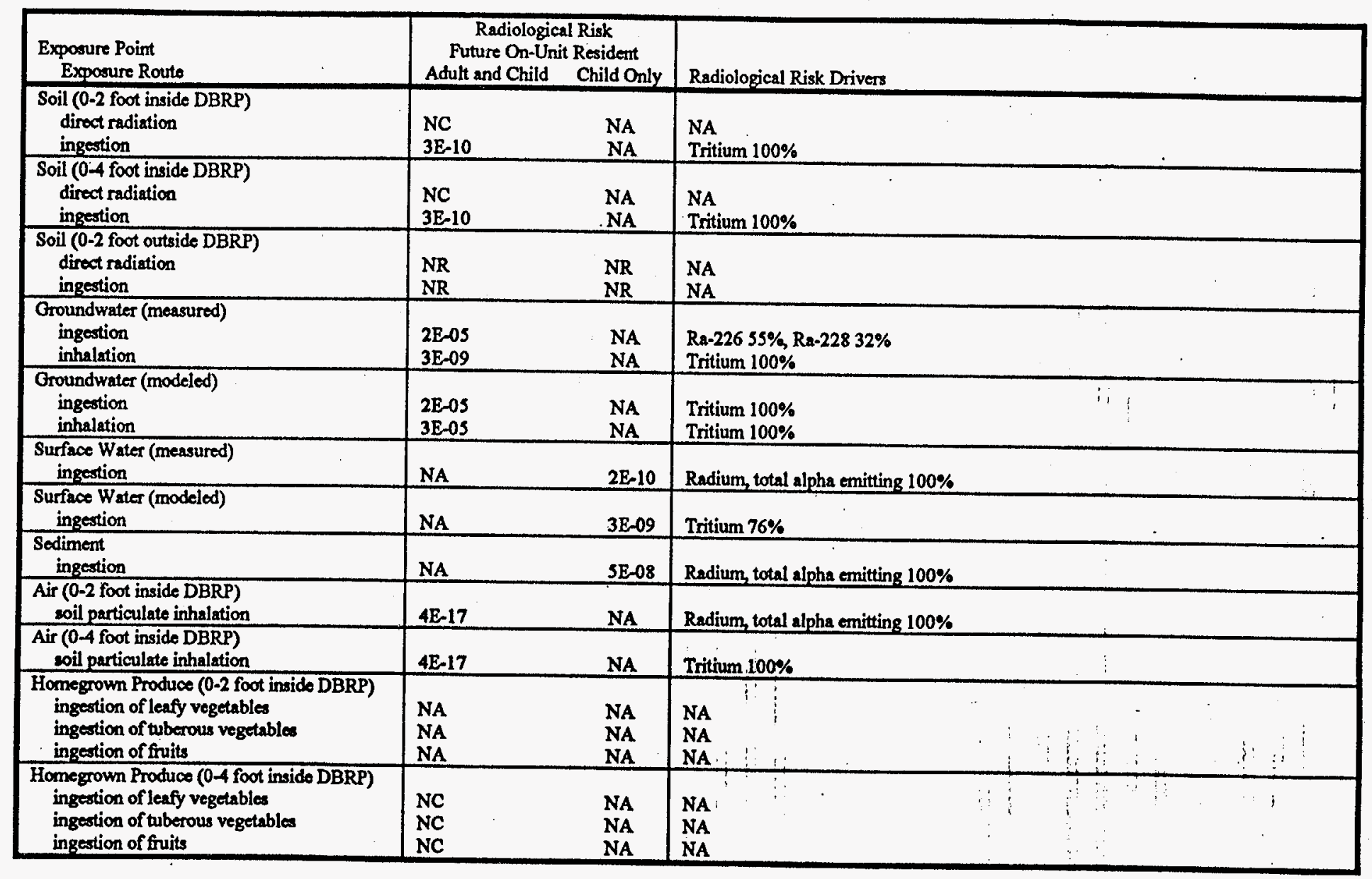

NA - Not applicable for this roceptor.

NC. No data was available for the toxicity of the COPCs in this medium, for this exposure route. Therefore, a quantitative riak value could not be calculated. NR - No ndiological COPCs in soils outside the pits.

Air and homegrown produce exposures are modeled values based on soil contaminant data. 
The groundwater ingestion and inhalation pathway yielded a $\mathrm{HI}$ of 50 from arsenic and manganese to future resident adults and children. This hazard is reduced to 6 for future on-unit workers.

\section{Future Land Use - Carcinogenic Risks}

Several exposure pathways for the future on-unit resident had estimated nonradiological carcinogenic risks exceeding the lower bound of the target risk range, $1.0 \times 10^{-6}$ (Tables 2 and 3). No contamination was found in concentrations that yielded risks greater than the upper bound of the risk range of $1.0 \times 10^{-4}$ except for arsenic by groundwater ingestion. Under the groundwater ingestion pathway, the risk due to arsenic to the future on-unit worker was $3.0 \mathrm{x}$ $10^{-4}$; to the future on-unit resident the risk was $1.0 \times 10^{-3}$. These risks were based on a single measured arsenic value in the groundwater which was less than the $\mathrm{MCl}$ for drinking water.

For the future on-unit worker, cancer risks for ingestion of soil from inside the DBRPs were equal to the EPA point of departure of $1.0 \times 10^{-6}$ for the 0-2.0 foot and 0-4.0 foot depth intervals. Estimated risks for dermal contact with soil and inhalation of soil particulates at both depths inside the DBRP were equal to $1.0 \times 10^{-6}$.

\section{Ecological Risk Assessment}

Based on characterization of the environmental setting and identification of potential receptor organisms, a conceptual site model was developed to determine the complete exposure pathways through which receptors could be exposed to COPCs.

Interpretation of the ecological significance of the unit-related contamination at the DBRP indicated that there was essentially no likelihood of unit-related chemicals causing significant impacts to the community of species in the vicinity of the unit.

\section{Site-Specific Considerations}

Site-specific considerations, based on the conclusions of the BRA and RFI/RI, which suggest limited or no potential for significant risk include:

1) The DBRP contain a large volume of buried non-hazardous waste material and cover soil.

2) The levels of contamination recognized during Phase II characterization are generally very low, there is a preponderance of nondetects. The contaminants are very stable chemically and exhibit limited mobility in the soil.

3) The groundwater monitoring program indicates that there has not been significant impact from the waste materials in the pits.

4) The DBRP are in a remote area which has been recommended as a future industrial zone by the Citizens Advisory Board (CAB) and in the Savannah River Site Future Use Project Report (DOE, 1996).

\section{Remedial Action Objectives}

Remedial action objectives specify unit-specific contaminants, media of concern, potential exposure pathways, and remediation goals. The remedial action objectives are based on the nature and extent of contamination, threatened resources, and the potential for human and environmental exposure. Initially, preliminary remediation goals are developed based upon Applicable or Relevant and Appropriate Requirements (ARARs), or other information from the RFI/RI Report and the BRA. These goals should be modified, as necessary, as more information concerning the unit and potential remedial technologies becomes available. Final remediation goals will be determined when the remedy is selected and shall establish acceptable exposure levels that are protective of human health and the environment.

Risk levels at or above the upper-bound of the target risk range $1.0 \times 10^{-1}$ are considered significant and are expected to undergo remediation.

Location-specific ARARs must consider Federal, State, and local requirements that reflect the physiographical and environmental characteristics of the unit or the immediate area. Remedial actions may be restricted or precluded depending on the location or characteristics of the unit and the resulting requirements. 
None of the risks associated with the soil in the DBRP was found to be greater than $1.0 \times 10^{-1}$. PCB-1260 from the 0-2 foot soir interval in Pit 431-D was the predominant risk driver for future residents, contributing $79 \%$ of the $1.0 \times$ $10^{-5}$ risk

The hazard index for this exposure scenario was 0.7. The only guidance that was exceeded for soil concentrations was for PCB-1260 which had a maximum value of $3.39 \mathrm{mg} / \mathrm{kg}$ in the $0-2$ foot interval of boring 12 in Pit 431-D. The to-beconsidered guidance for PCBs is recommended soil action levels of $1.0 \mathrm{mg} / \mathrm{kg}$ for residential use and 10-25 mg/kg for industrial use (EPA, 1990). The PCB-1260 concentration in Pit 431-D is well below the range for industrial land use.

VII. Description of the Considered Alternatives for the DBRP Source Control Operable Unit

The RFI/RI and BRA indicate the DBRP pose minimal risk to the environment. The risk to future on-unit workers is only $1.0 \times 10^{-6}$. Ingestion of soil in the top two foot layer by future residents poses a risk of $1.0 \times 10^{-5}$, primarily from PCB-1260. The Corrective Measures Study/Focused Feasibility Study (CMS/FFS) was developed to consider possible actions which could reduce the risks to $1.0 \times 10^{-6}$ or less.

A broad suite of treatment alternatives has already been considered in the F-Area Burning/Rubble Pits (231-F, 231-IF and 2312F) Corrective Measures Study/Feasibility Study (U) (WSRC, 1996a). Both sets of burning/rubble pits received similar wastes which were managed under similar conditions and practices; similar constituents of concern have been recognized for both facilities. On July 20, 1995, SRS, SCDHEC, and EPA held a scoping meeting for the DBRP CMS/FS. The agenda of this meeting included discussion of the site specific considerations and uncertainties, the limited risks associated with the DBRP, and the CAB proposed industrial land use zones. The conclusion of the scoping meeting was that focusing on a limited suite of alternatives in the feasibility study for the DBRP would be appropriate. Therefore, SRS conducted the CMS/FFS (WSRC, 1996b) for the
DBRP, reducing the number of treatment options to be considered to the five alternatives discussed in the following paragraphs.

Five alternatives were evaluated for remodial action at the DBRP source control operable unit. Each alternative is described below.

\section{Alternative 1 No Action}

Under this alternative, no action would be taken at the DBRP. - EPA policy and regulations require consideration of a no action alternative to serve as a basis against which other alternatives can be compared. Because no further action would be taken and the DBRP would remain in their present condition, there are no costs associated with this alternative and there would be no reduction of risk. Potential risks of $1.0 \times 10^{-5}$ due to soil ingestion and 1.0 $x 10^{-3}$ from ingestion and inhalation of groundwater would remain for possible future residents. However, the groundwater risk is believed to be overestimated based on the groundwater monitoring history and contaminant concentrations in the DBRP soil as discussed in Section V.

\section{Alternative 2 Institutional Controls}

Under this alternative, institutional controls would be implemented at the DBRP. Implementation of this alternative will require both near- and long-term actions. For the nearterm, signs will be posted indicating that this area was used to manage hazardous materials. In addition, existing SRS access controls will be used to maintain the use of this site for industrial use only.

In the long-term, if the property is ever transferred to non-federal ownership, the U.S. Government would create a deed for the new property owner in compliance with Section 120(h) of CERCLA. The deed would include notification disclosing former DBRP waste management and disposal activities, results from groundwater monitoring, and remedial actions taken on the site. The deed notification would, in perpetuity, notify any potential purchaser that the property has been used for the management and disposal of non-hazardous, inert construction debris, and that wastes containing hazardous substances, such as degreasers and 
solvents, were also managed and burned on the site.

The deed would also include deed restrictions precluding residential use of the property. However, the need for these deed restrictions could be reevaluated at the time of transfer in the event that contamination no longer poses an unacceptable risk under residential use.

In addition, if the site is ever transferred to nonfederal ownership, a survey plat of the area will be prepared, certified by a professional land surveyor, and recorded with the appropriate county recording agency.

There are no construction costs associated with this alternative. The cost for surveying the land and filing with the Barnwell County Records is estimated to be $\$ 2,000$. If five year reviews of remedy are required, the estimated present value for these reviews over the next 30 years is $\$ 8,000$. The total present value costs for Alternative 2 are $\$ 10,000$. Additional groundwater monitoring and reporting costs would total about $\$ 12,000$ annually, these costs may not continue indefinitely and are not included in the total cost used for comparison.

With essentially no further action except for the modest cost of deed notifications and restrictions upon transfer of the land and five year reviews, under Alternative 2 Institutional Controls, risks attributable to future workers at the DBRP would be $1.0 \times 10^{-6}$.

\section{Alternative 3 Native Soil Cover (4')}

A four foot thick cover of native soil would be installed over the present surface of the DBRP to reduce the likelihood that future excavation for construction of a typical basement would expose waste or contaminated soil. If the property is ever transferred to private ownership, in compliance with CERCLA 120(h), the U. S. Government would create a deed with notifications and restrictions similar to those identified in Alternative 2. Future deed restrictions on excavation below four feet would be necessary to prevent potential exposure of future workers or residents to buried waste which may contain low concentrations of hazardous constituents.
The preparation of a Remedial Design/Remedial Action Work Plan would cost \$SO,000. The construction costs associated with this alternative are estimated at $\$ 160,000$ for the installation of a four foot thick native soil covier. The cost for surveying the land and filing with the Barnwell County Records is estimated to be $\$ 2,000$. Maintenance costs for 30 years are extimated at $\$ 15,000$. If five year reviews would be required; the estimated present value for these reviews over the next $\mathbf{3 0}$ years is $\$ \mathbf{8 , 0 0 0}$. Total present value costs for this alternative are estimated at $\$ 235,000$.

With deed restrictions upon the transfer of the land to non-federal ownership per Section 120(h) of CERCLA, the risk to future workers and possible future residents would be reduced to less than $1.0 \times 10^{-6}$. The need for the deed restrictions would be reevaluated prior to transfer.

\section{Alternative 4 Thermal Desorption Incineration}

Under this alternative, the upper two feet of contaminated soil would be excavated for treatment to eliminate the PCB-1260, BaP, and OCDD. The soil would be fed through a high temperature rotary kiln to extract the volatile organic' contaminants from the soil. The extracted gases would then be destroyed in the incinerator. : The treated soil would be returned to the site and vegetation would be established to prevent erosion. If the property is ever transferred to private ownership, in compliance with CERCLA 120(h), the U. S. Government would create $a$ deed with notifications and restrictions similar to those identified in Alternative 2. Future deed restrictions (upon transfer of the land to non-federal ownership) on excavation below two feet would be necessary to prevent potential exposure of future workers or residents to buried waste which may contain low levels of hazardous constituents. The need for these deed restrictions could be reevaluated at the time of transfer in the event that contamination no longer poses an unacceptable risk under residential use.

Preparation of the Remedial Design/Remedial Action Work Plan to implement this alternative would cost \$150,000. A National Emission 
Standards for Hazardous Air Pollutants permit would be required at a cost of $\$ 150,000$ because of the potential for atmospheric releases during remediation. The treatment cost for this alternative would be $\$ 1,500,000$ and the deed restriction on excavation below two feet would cost $\$ 2,000$ for a total cost of $\$ 1,502,000$.

This alternative is protective of human health and would permanently reduce risk to less than $1.0 \mathrm{x}$ $10^{-6}$ for ingestion of soil from PCB-1260 for future on-site workers and future residents.

\section{Alternutive 5 Offsite Soil Disposal}

Under this alternative, the upper two feet of contaminated soil would be excavated and transperted to a licensed offsite disposal facility. The excavation would be filled to grade with clean rative soil and cover vegetation would be established. If the property is ever transferred to private ownership, the U. S. Government would create $a$ deed with notifications and restrictions similar to those identified in Alternative 2 in compliance with CERCLA 120(h). The potential risk for exposure of future workers and possible residents to low concentrations of hazardous constituents in the remaining waste would necessitate the filing of a deed restriction on excavation below two feet upon the transfer of the land to non-federal ownership. The need for these deed restrictions could be reevaluated at the time of transfer in the event that contamination no longer poses an unacceptable risk under residential use.

The preparation of a Remedial Design/Remedial Action Work Plan would cost $\$ 150,000$. The cost for excavation, transportation, disposal fees, and backfilling would be $\$ 932,000$. The total cost for this would be $\$ 1,084,000$, including $\$ 2,000$ for recording the deed notifications and restrictions.

The risk to future workers and possible future residents would be reduced to less than $1.0 \mathrm{x}$ $10^{-6}$ frim ingestion of PCB- 1260 contaminated soil.
VII. Summary of Comparative Analyais of the Alternatives

\section{Description of Nine Evaluation Criteria}

Each of the remedial alternatives was evaluated using the nine criteria established by the National Oil and Hazardous Substances Contingency Plan (NCP). The criteria were derived from the statutory requirements of CERCLA Section 121. The NCP [40 CFR $\$ 300.430$ (e) (9)] sets forth -. nine evaluation criteria that provide the basis for evaluating alternatives and selecting a remedy. - The criteria are:

- overall protection of human bealth and the environment,

- compliance with ARARs,

- long-term effectiveness and permanence,

- reduction of toxicity, mobility, or volume through treatment,

- short-term effectiveness,

- implementability,

- cost,

- state acceptance, and

- community acceptance.

In selecting the preferred alternative, the above mentioned criteria were used to evaluate the alternatives developed in the $D$-Area Burning/Rubble Pits (431-D and 431-1D) Corrective Measures Study/Focused Feasibility Study (U) (WSRC, 1996b). Seven of the criteria are used to evaluate all the alternatives, based on human health and environmental protection, cost, and feasibility issues. The preferred alternative is further evaluated based on the final two criteria: state acceptance and community acceptance. Brief descriptions of all nine criteria are given below.

Overall Protection of Human Health and the Environment - The remedial alternatives are assessed to determine the degroe to which each alternative eliminates, reduces, or controls threats to human health and the environment through treatment, engineering methods, or institutional controls.

Compliance with Applicable or Relevant and Appropriate Requirements - ARARs are Federal and state environmental regulations that establish standards which remedial actions must meet. There are three types of ARARs: (1) chemical- 
specific, (2) location-specific, and (3) actionspecific.

Chemical-specific ARARs are usually health- or risk-based levels or methodologies which, when applied to unit-specific conditions, result in the establishment of : numerical values. Often these numerical values are promulgated in Federal or state regulations.

Location-specific ARARs are restrictions placed on the concentration of hazardous substances or the conduct of activities solely because they are in specific locations. Some examples of specific locations include floodplains, wetlands, historic places, and sensitive ecosystems or habitats.

Action-specific ARARs are usually technology- or remedial activity-based requirements or limitations on actions taken with respect to hazardous substances or unit-specific conditions. These requirements are triggered by the particular remedial activities that are selected to accomplish a remety.

The remedial activities are assessed to determine whether they attain ARARs or provide grounds for invoking one of the five waivers for ARARs. These waivers are:

- the remedial action is an interim measure and will become a part of a total remedial action that will attain the ARAR,

- compliance will result in greater risk to human health and the enviropiment than other alternatives,

- compliance is technically impracticable from an engineering perspective,

- the alternative remedial action will attain an equivalent standard of performance through use of another method or approach,

- the state has not consistently applied the promulgated requirement in similar circumstances or at other remedial action sites in the state.

In addition to ARARs, compliance with other criteria, guidance, and proposed standards that are not legally binding, but may provide useful information or recommended procedures should be reviewed as To-Be-Considered when setting remedial objectives.
Long-Term Effectiveness and Permanence - The remedial alternatives are assessed based on their ability to maintain reliable protection of human health and the environment after implementation.

Reduction of Toxicity Mobility or Volume Through Treatment - The remedial alternatives are assessed based on the degree to which they employ treatment that reduces toxicity (the harmful nature of the contaminants), mobility (ability of the contaminants to move through the environment), or volume of contaminants associated with the unit.

Short-Term Effectiveness - The remedial alternatives are assessed considering factors relevant to implementation of the remedial action, including risks to the community during implementation, impacts on workers, potential environmental impacts (e.g., air emissions), and the time until protection is achieved.

Implementability - The remedial aiternatives are assessed by considering the difficulty of implementing the alternative including technical feasibility,-- constructability, reliability of technology, ease of undertaking additional remedial actions (if required), : monitoring considerations, administrative feasibility (regulatory requirements), and availability of services and materials.

Cost - The evaluation of remedial alternatives must include capital and operational and maintenance costs. Present value costs are estimated within $+50 /-30$ percent, per : EPA guidance. The cost estimates given with each alternative are prepared from information available at the time of the estimate. The final costs of the project will depend on actual labor and material costs, actual site conditions, productivity, competitive market conditions, final project scope, final project schedule, and other variable factors. As a result, the final project costs may. vary from the estimates presented herein.

State Acceptance - In accordance with the FFA, the State is required to comment on/approve the RFI/RI Report, the Baseline Risk Assessment, the Corrective Measures Study/Feasibility Study, and the Statement of Basis/Proposed Plan.

Community Acceptance - The community acceptance of the preferred alternative is assessed 
by giving the public an opportunity to comment on the remedy selection process. A public comment period was held and public comments concerning the proposed remedy are addressed in the Responsiveness Summary of this Record - of Decision.

\section{Detailed Evaluation}

The remedial action alternatives discussed in Section VII have been evaluated using the nine criteria just described. Tables 4 through 8 present the evaluation of the soil remedial alternatives.

\section{The Selected Remedy}

Based on the BRA, the DBRP unit soil poses a risk of $1.0 \times 10^{-6}$ for future workers in an industrial land use scenario via ingestion of the soil in the top 2 foot layer. Analysis of the risk evaluation indicated that calculated risks to future workers and residents under the inhalation and ingestion of groundwater pathway were exaggerated because of conservative assumptions in the modeling. The probable condition is that the DBRP source unit is not contributing to groundwater contamination. As a result, no remedial action for the groundwater with a period of continued monitoring for confirmation is the only appropriate action.

Institutional Controls (Alternative 2) for the DBRP Source Unit and no remedial action for the groundwater with a period of confirmatory groundwater monitoring is the preferred action at the DBRP because:

1) the groundwater history at the DBRP (summarized in Section $V$ ) indicates low frequency of occurrences at low concentrations of gross alpha and total radium,

2) the DBRP soils do not represent a credible threat to the quality of groundwater in the future.

A plan for continued annual groundwater monitoring, during the second quarter of each calendar year, for the five wells at the DBRP will be included in the post-ROD document, the Corrective Measures Implementation/ Remedial Action Report (CMI/RAR). The groundwater samples will be analyzed for following proposed list of constituents many of which have not been detected in the groundwater at the DBRP since monitoring began in 1983.

arsenic-
benzene
benzo(a)anthracene
benzo(a)pyrene
benzo(b)fluoranthene
benzo(k)fluoranthene
chromium
chrysene
-1,2-dichloroethane
dichloromethane
endrin
manganese
octachlorodibenzo-p-dioxin
PCB-1260
total radium
1,1,2-trichloroethane
tritium

The CMI/RAR will contain a detailed monitoring strategy which will outline the submittal schedule and - contents of the monitoring reports, which: will include an analysis of the data, a conclusion, and a recommendation. The recommendation section of the CMI/RAR will provide for appropriate changes to the monitoring program with SCDHEC and EPA concurrence. 
Table 4. Summary of the Evaluation of Alternative 1 No Action under the Nine CERCLA Criteria.

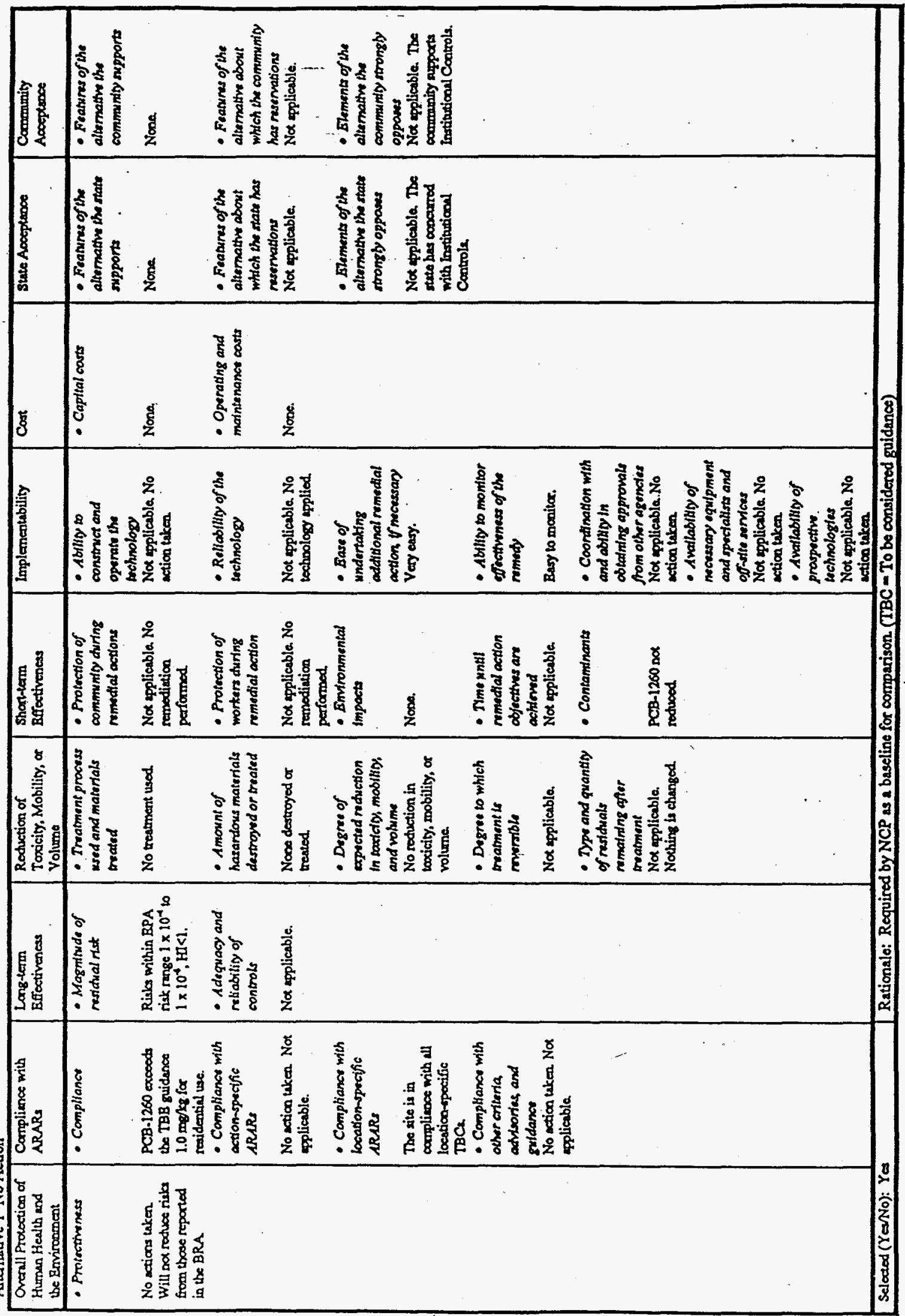


Table 5. Summary of the Evaluation of Alternative 2 Institutional Controls under the Nine CERCLA Criteria.

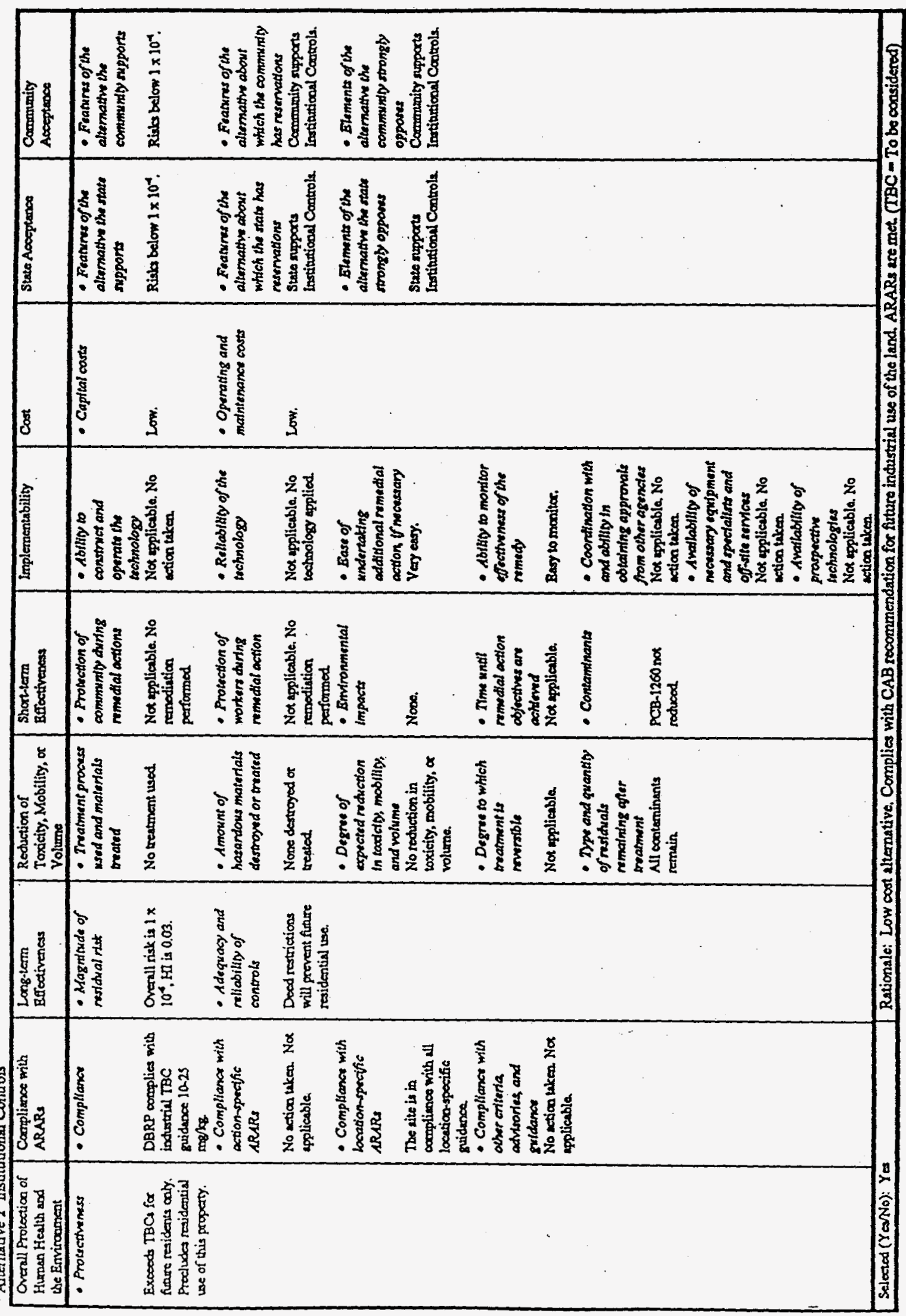


Table 6. Summary of the Evaluation of Alternative 3 Native Soil Cover (4') under the Nine CERCLA Criteria.

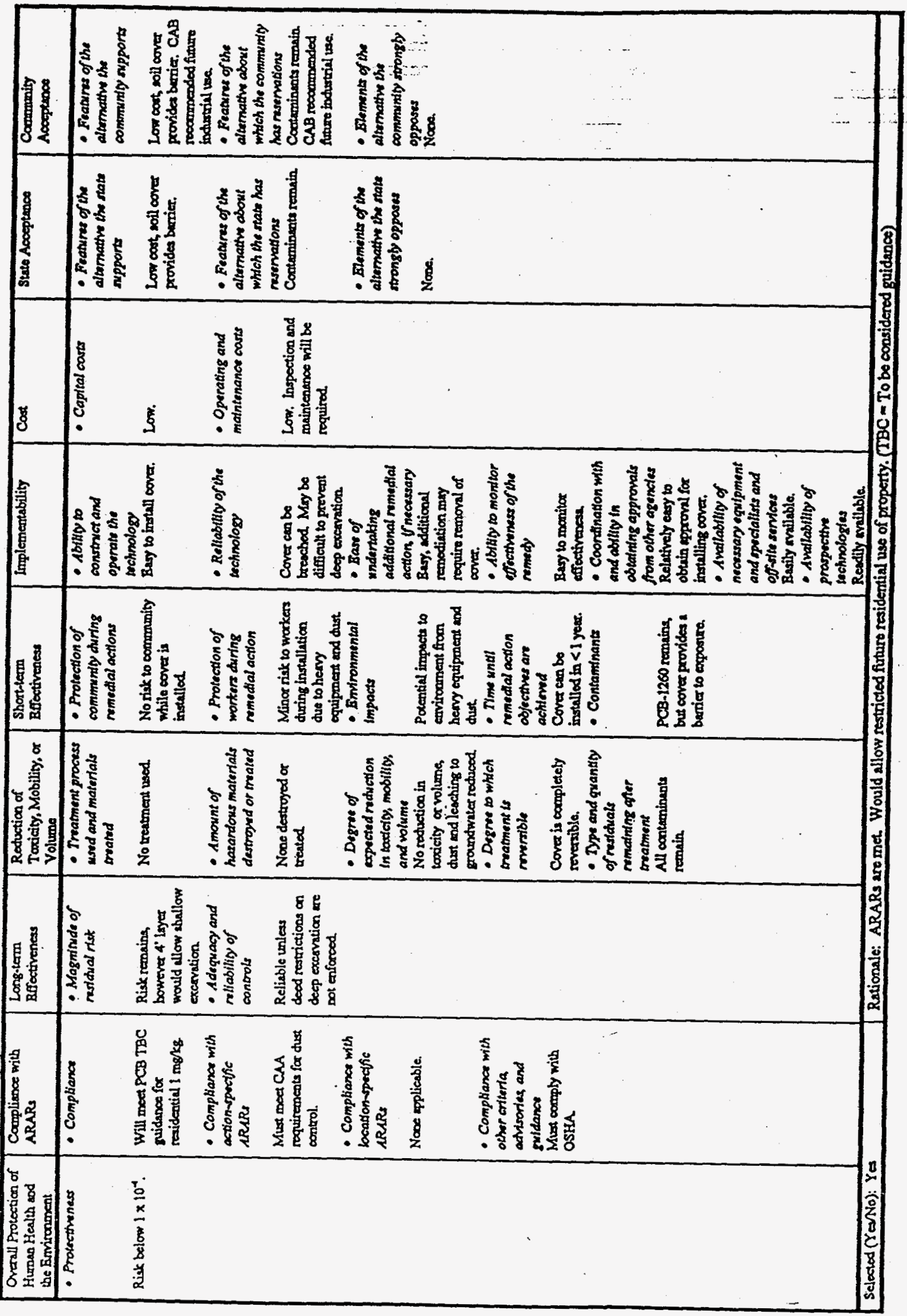


Alternative 4 Thermal Desorption/Incineration

\begin{tabular}{|c|c|c|c|c|c|c|c|c|}
\hline $\begin{array}{l}\text { Dreall procection of } \\
\text { Human Hesth and } \\
\text { the Envirament }\end{array}$ & $\begin{array}{l}\text { Complimoce with } \\
\text { ARARs }\end{array}$ & $\begin{array}{l}\text { Long-lerm } \\
\text { Effoctiveness }\end{array}$ & $\begin{array}{l}\text { Recuction of } \\
\text { Toxicity, Mobility, } \propto \\
\text { Volume }\end{array}$ & $\begin{array}{l}\text { Short-tarm } \\
\text { Bffectiveness }\end{array}$ & Implementability & Cost & State Acceptence & $\begin{array}{l}\text { Cormminity } \\
\text { Acosptance }\end{array}$ \\
\hline $\begin{array}{l}\text { Ofters complete } \\
\text { procection of thumen } \\
\text { bealth and the } \\
\text { ervircenment. }\end{array}$ & 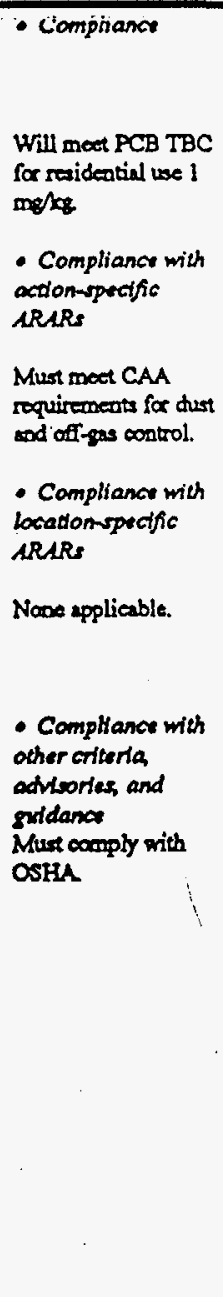 & $\begin{array}{l}\text { - Magnilude of } \\
\text { rastidual rist } \\
\text { Remaining risk will } \\
\text { be below } 1 \times 10^{4} \text {. } \\
\text { - Adequacy and } \\
\text { rebiability of } \\
\text { controls } \\
\text { Reliable unless } \\
\text { deed restrictions on } \\
\text { dexp excruation aro } \\
\text { not enforcod }\end{array}$ & 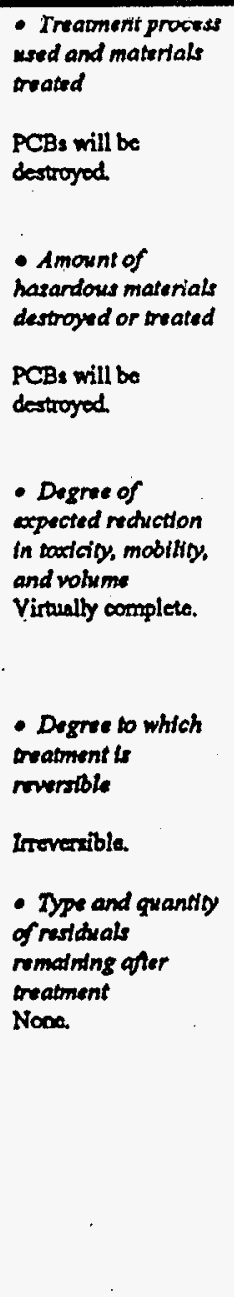 & 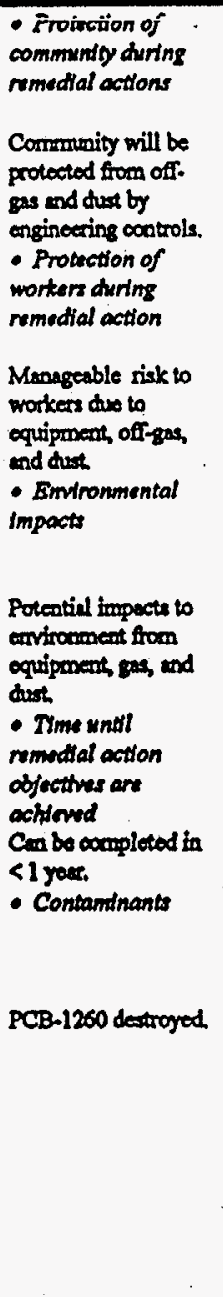 & 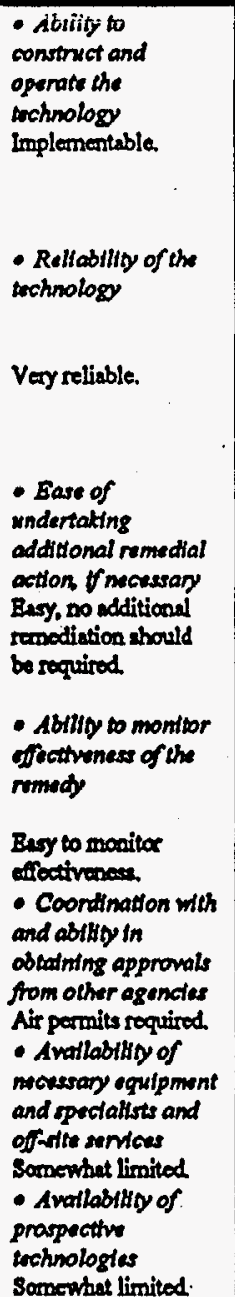 & $\begin{array}{l}\text { Hight } \\
\text { - Operating and } \\
\text { maintenance casts } \\
\text { High. Subsequent } \\
\text { maintenence will not } \\
\text { be required. }\end{array}$ & 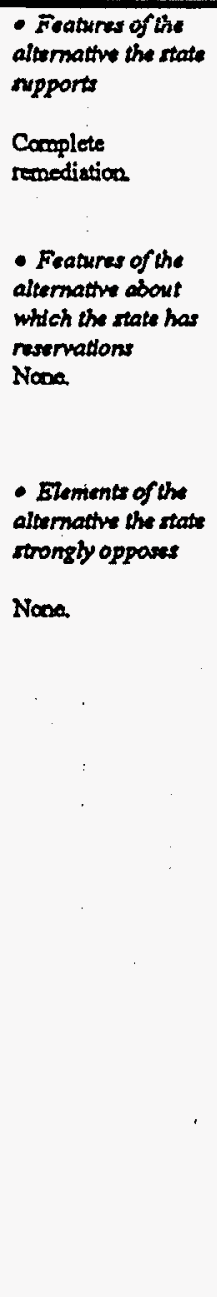 & 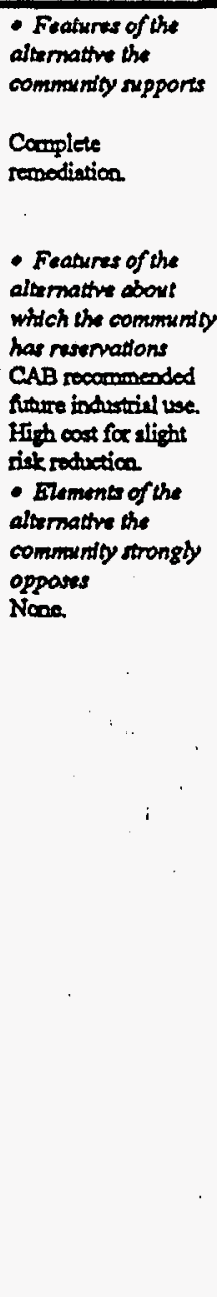 \\
\hline
\end{tabular}




\begin{tabular}{|c|c|c|c|c|c|c|c|c|}
\hline $\begin{array}{l}\text { Overall Proloction of } \\
\text { Humen Health and } \\
\text { the Envirangent }\end{array}$ & $\begin{array}{l}\text { Compliance with } \\
\text { ARARe }\end{array}$ & $\begin{array}{l}\text { Long-lam } \\
\text { Bffectiveness }\end{array}$ & $\begin{array}{l}\text { Retuction of } \\
\text { Toxicity, Mobility, of } \\
\text { Volume }\end{array}$ & $\begin{array}{l}\text { Short-lem } \\
\text { Bffoctiveness }\end{array}$ & Implementability & $\cos t$ & State Accoptence & $\begin{array}{l}\text { Commininity } \\
\text { Acosptances }\end{array}$ \\
\hline 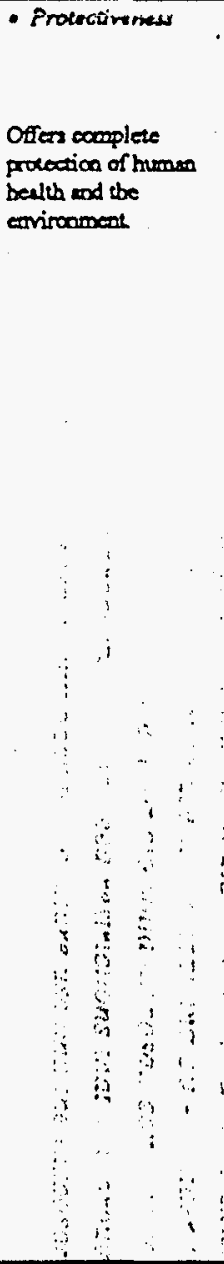 & 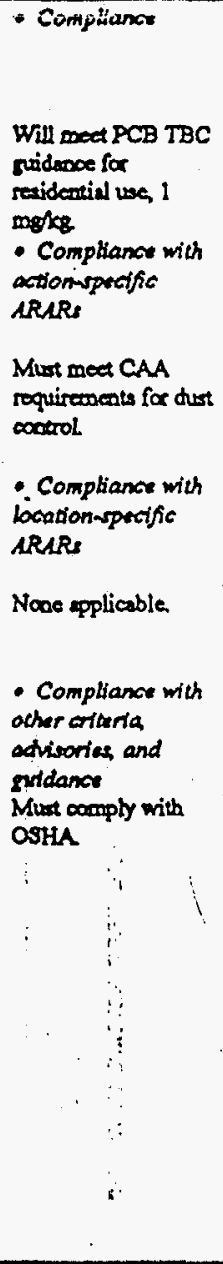 & 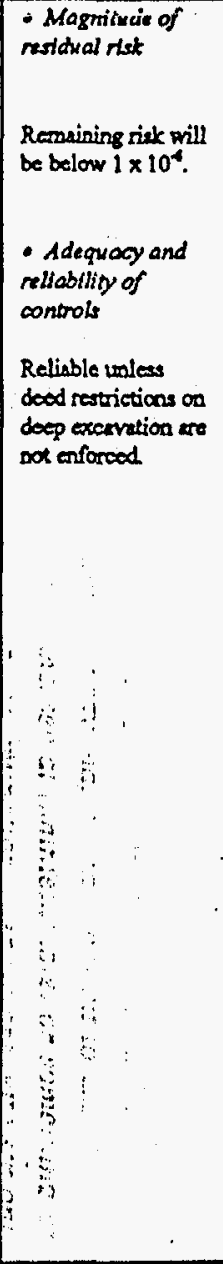 & 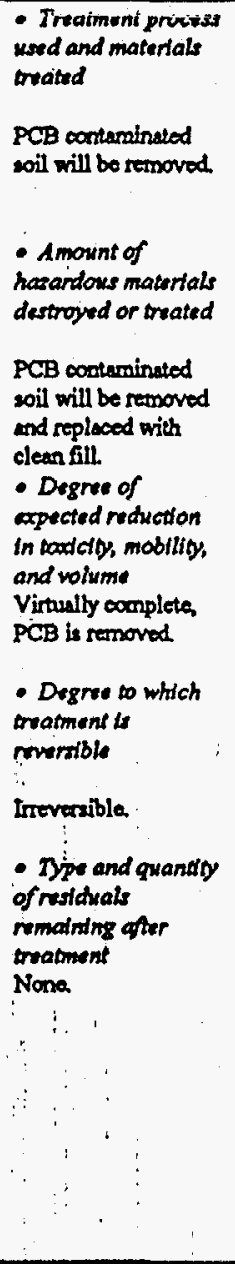 & 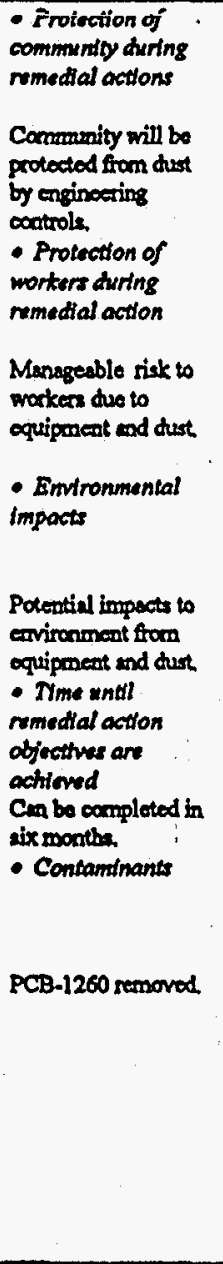 & 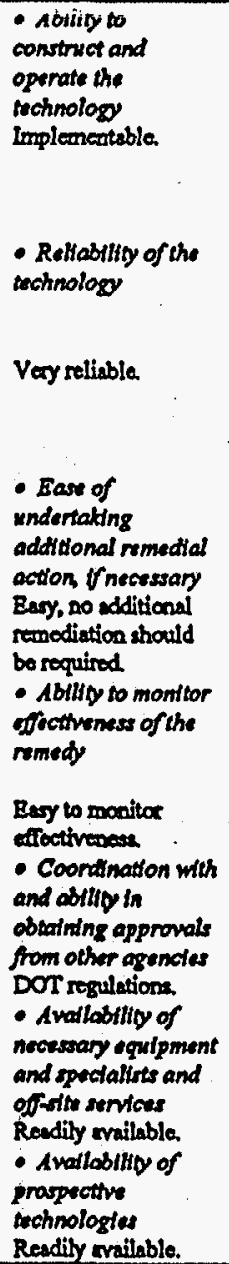 & $\begin{array}{l}\text { - Operating and } \\
\text { matintenancer casts } \\
\text { Hight subsequent } \\
\text { maintenasces will not } \\
\text { be required. }\end{array}$ & 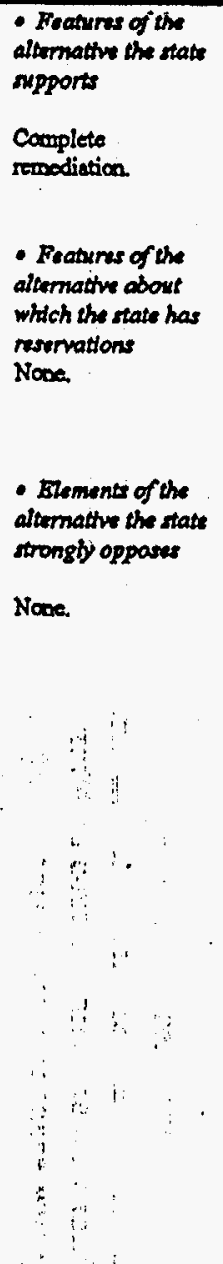 & 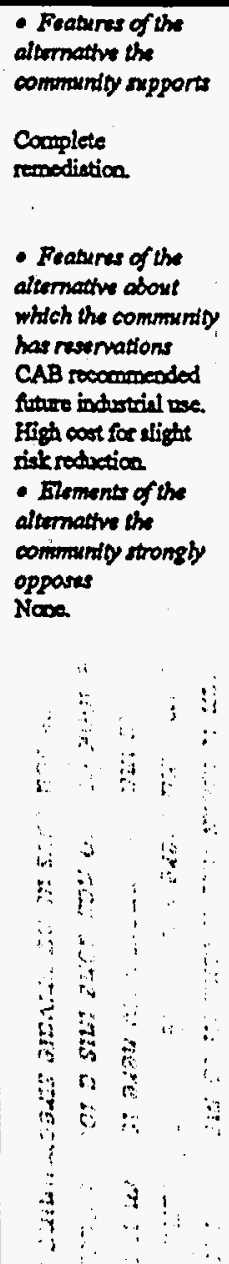 \\
\hline \multicolumn{2}{|l|}{ Selectod $\left(\mathrm{Y}_{\mathrm{c}} \mathrm{N} / \mathrm{No}\right):-\mathrm{Y}_{\varphi}$} & \multicolumn{7}{|c|}{ Rationale: ARARs ere met. Would allow future residential use of property with restrictions on excavation below 2 feet (TBC - To be considered) } \\
\hline 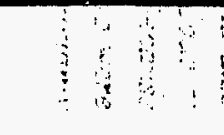 & $\therefore \quad \because$ & 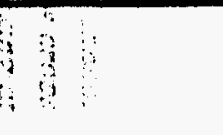 & $\begin{array}{lll}\vdots & \vdots & \\
\vdots & \vdots & \vdots \\
\vdots & \vdots & \vdots \\
\vdots & 1 & \end{array}$ & & & & 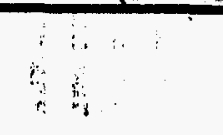 & $\begin{array}{c}3 \\
? \\
\vdots \\
\vdots\end{array}$ \\
\hline
\end{tabular}


Implementation of this alternative will require both near- and long-term actions. For the nearterm, signs will be posted indicating that this area was used to manage hazardous materials. In addition, existing SRS access controls will be used to maintain the use of this site for industrial use only.

In the long-term, if the property is ever transferred to non-federal ownership, the U.S. Government will create a deed for the new property owner in compliance with Section 120(h) of CERCLA. The deed will include notification disclosing former waste management and disposal activities, results from groundwater monitoring, and remedial actions taken on the site. The deed notification will, in perpetuity, notify any potential purchaser that the property has been used for the management and disposal of non-hazardous, inert construction debris, and that wastes containing hazardous substances, such as degreasers and solvents, were also managed and burned on the site.

The deed will also include deed restrictions precluding residential use of the property. However, the need for these deed restrictions could be reevaluated at the time of transfer in the event that contamination no longer poses an unacceptable risk under residential use.

In addition, if the site is ever transferred to nonfederal ownership, a survey plat of the area will be prepared, certified by a professional land surveyor, and recorded with the appropriate county recording agency.

The Institutional Controls Alternative is intended to be the final action for the DBRP Source Unit. The solution is intended to be permanent and effective in both the long and near terms. This alternative is considered to be the least cost option which is still protective of human health and the environment.

The SCDHEC has modified the SRS RCRA permit to incorporate the selected remedy.

This proposal is consistent with EPA guidance and is an effective use of risk management principles.

\section{Statutory Determinations}

Based on the DBRP RFIRI Report and the BRA, the DBRP source operable unit poses no significant risk to the environment and minimal risk .. to human health. Therefore, a determination has been made that Institutional Controls are sufficiently protective of human health and the environment for the remaining contamination in the DBRP soils and groundwater.

The selected remedy is protective of human health and the environment, complies with Federal and State of South Carolina requirements that are legally applicable or relevant and appropriate to the remedial action, and is cost-effective. The random distribution and low levels of contamination preclude a remedy in which treatment is a practical alternative. Institutional Controls will result in hazardous substances, pollutants, or contaminants remaining in the waste unit. Because treatment of the principal threats of the site was found to be impracticable, this remedy does not satisfy the statutory preference for treatment as a principal element.

Section 300.430 (f)(4)(ii) of the NCP requires that a five-year review of the ROD be performed if hazardous substances, pollutants, or contaminants remain in the waste unit. The three Parties, DOE, SCDHEC, and EPA, have determined that a Five Year Review of the ROD for the DBRP will be performed to ensure continued protection of human health and the environment.

\section{Explanation of Significant Changes}

The Statement of Basis/Proposed Plan and the draft RCRA permit modification provided for involvement with the community through a document review process and a public comment period. A public meeting was advertised and held on October 15. Comments that were received during the 45-day public comment period (September 17 through October 31, 1996) are addressed in Appendix $A$ of this Rocord of Decision and are available with the final RCRA permit. 
The only changes to the remedy proposed for the DBRP in the Statement of Basis/Proposed Plan (WSRC, 1996c) are: (1) that the probable condition is that no significant groundwater contamination is originating in the DBRP and no remedial action for the groundwater with a period of continued monitoring for confirmation of no leaching to groundwater is the only appropriate action, and (2) it was determined that it was not appropriate to append the continued groundwater monitoring plan to the ROD as proposed in the Statement of Basis/Proposed Plan. The plan for continued groundwater monitoring will be included in the CMI/RAR. In the event that the probable condition is no longer appropriate, $D O E$ will evaluate the need for remedial action.

\section{Responsiveness Summary}

There were three comments received during the public comment period. The Responsiveness Summary (see Appendix A) of this Record of Decision addresses these comments.

\section{Post-ROD Document Schedule}

The post-ROD document schedule is listed below and is illustrated in Figure 4:

1. Corrective Measures Implementation/ Remedial Action Report (CMIRAR) Revision 0 for the DBRP will be submitted for EPA and SCDHEC review four months after issuance of the ROD.

2. EPA and SCDHEC review of the DBRP CMI/RAR Revision 0 will last 90 days.

3. SRS revision of the DBRP CMIRAR Revision 0 will be completed in 60 days after receipt of all regulatory comments.

4. EPA and SCDHEC final review and approval of the DBRP CMURAR Revision 1 will last 30 days. 


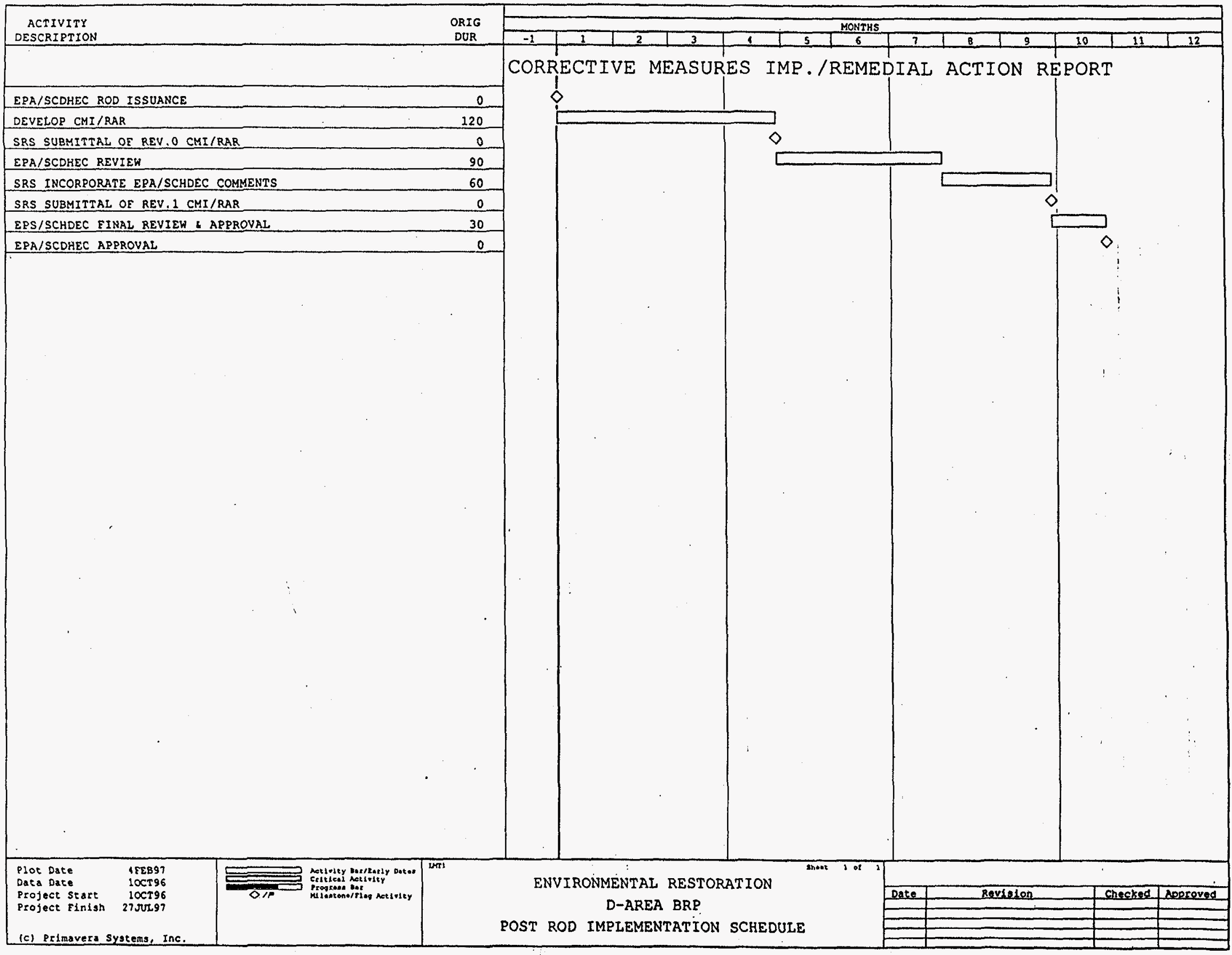




\section{REFERENCES}

DOE (U. S. Department of Energy), 1994. Public Involvement, A Plan for Savannah River Site. Savannah River Operations Office, Aiken, South Carolina (1994).

DOE, 1996. Savannah River Site Future Use Project Report, Stakeholder Recommendations for SRS Land and Facilities $(U)$. Savannah River Operations Office, Aiken, South Carolina (January 1996).

EPA, 1990. (U. S. Environmental Protection Agency). A Guide on Remedial Actions at Superfund Sites with PCB Contamination. Office of Emergency and Remedial Response. Directive 9355.4-01 FS (August 1990).

EPA, 1995. Supplemental Guidance to RAGS: Region 4 Bulletins; Development of RiskBased Remedial Options, Human Health Risk Assessment Bulletin No. 5 (November 1995).

Federal Facility Agreement, 1993. Federal Facility Agreement for the Savannah River Site, Administrative Docket No. 89-05-FF, (Effective Date: August 16, 1993).

WSRC (Westinghouse Savannah - River Company), 1994. Data Summary Report for the D-Area Burning/Rubble Pits. WSRCRP-94-709, Rev. 0, Westinghouse Savannah
River Company, Aiken, South Carolina (1994).

WSRC, 1995a. Baseline Risk Assessment for the-D-Area BurningAubble Pits (U). WSRC-TR-94-708, Rev. 1, Westinghouse Savannah River Company, Aiken, South Carolina (1995).

WSRC, 1995b. RFI/RI Report for D-Area Burning/Rubble Pits (431-D and 431-ID)(U). . WSRC-RP-94-707, Rev. 1, V Westinghouse Savannah River Company, Aiken, South Carolina (1995).

WSRC, 1996a F-Area Burning/Rubble Pits (231-F, 231-1F, and 231-2F) Corrective Measures Study/Feasibility Study (U). WSRC-RP-95-660, Rev. 1, Westinghouse Savannah River Company, Aiken, South Carolina (March 1996).

WSRC, 1996b. D-Area Burning/Rubble Pits (431-D and 431-ID) Corrective Measures Study/Focused Feasibility Study (U). WSRC-RP-95-904, Rev. 1, Westinghouse Savannah River Company, Aiken, South Carolina (March 1996).

WSRC, 1996c. Statement of Basis/Proposed Plan for the D-Area Buming/Rubble Pits (431-D and 431-ID) $(U)$. WSRC-RP-95905, Rev. 1.3; Westinghouse Savannah River Company, Aiken, South Carolina (August 1996). 


\title{
Record of Decision \\ Remedial Alternative Selection for the \\ D-Area Burning/Rubble Pits (431-D and 431-1D) (U)
}

\author{
WSRC-RP-96-867 \\ Revision 1 \\ February 1997
}

\author{
Appendix A \\ Responsiveness Summary
}

The 45-day public comment period for the Statement of Basis/Proposed Plan for the D-Area Burning/Rubble Pits (431-D and 431-1D) (U) began on September 17, 1996 and ended on October 31, 1996. A public meeting was held on October 15, 1996. Specific comments and responses are found below. The comments are italicized and the responses are bolded.

\section{Public: Meeting Comments}

The following comments were received during the Limited Action Proposed Plans/Permit Modifications presentations. These comments were taken from the October 15, 1996 Public Meeting as recorded in the Savannah River Site Information Exchange transcript.

Comnent 1: Public Citizen: "What risk is there for animals or I guess future environmental, like if you were going to turn this into a park?"

Response to Comment 1: As a part of the baseline risk assessment process for the DBRP, an ecological risk assessment was conducted to assess the potential impacts to biota caused by exposure to chemical and radiological constituents at the DBRP. A site ecological reconnaissance survey was conducted in April 1994. No stressed vegetation was observed on or around the DBRP. No threatened and endangered species were observed in the vicinity of the DBRP or the adjacent ephemeral stream.

Based on the ecological risk assessment, there is little or no risk of adverse ecological effects from the DBRP. Therefore, if the unit is turned into a park in the future, the animal and plant species would not be affected. 
Comment 2: Public Citizen: "Are you using like private landfills and private - ot I guess what other communities have developed? I mean it looks like a landfill to me. And it looks like there are landfills all over the country and there's a whole lot of landfills that have been turned into like parks and stuff. Is that an opportunity here to turn it into a park or to use private models and maybe look at who has done this a lot? I guess the EPA guy was talking about streamlining. Are you guys using private streamlining ideas?"

Response to Comment 2: $\quad$ There is a proposal for the entire Savannah River Site (SRS) to become a national research park at some time in the future. Even now, the SRS is a national environmental research park and as such, the site is/will be used for environmental research. For the institutional control units, the only thing that our remedial decision has done is to state that on this waste unit there will not be any residential use.

Due to its location, approximately 0.7 mile from the Savannah River and the absence of remarkable scenery, the DBRP would be unlikely to become a recreational site. The risk levels for the soils alone barely exceed the threshold for residential use; the presence of buried waste should not interfere with the use of the DBRP as a park. However, there is groundwater contamination at the DBRP that could preclude use of the local shallow groundwater as a source of drinking water. Groundwater risk modeling indicates that there are constituents present which could exceed primary drinking water atandards in the future.

It should also be noted that the use of the DBRP as an environmental research or recreational park would be evaluated at the time of property transfer if ownership of the land is ever transferred from the Federal government. DBRP is one of the first burning/rubble pits at SRS to be evaluated and will contribute to a streamlined process for characterization, technology evaluation, and determining likely response actions at subsequent burning/rubble pits.

The following comment was received during the Formal Public Comment Session.

Comment 3: Mike Rourak: My name is Mike Rourak and my question is directed to Mr. Brian Hennessey's earlier discussion (unintelligible) Silverton Road property, for example. In the Future Use Manual that was sent out to some of us about the disposal of close to a million acres of property for DOE, in your deed restrictions there's things that we cannot do. And we're going to need a little bit before we can respond back to Washington. Those of us who received the manual, we almost are going to need to know what those deed restrictions are because if we cannot have a subdivision then there's no need to bid the price accordingly or say that's what we want to use it for. If we cannot graze cattle here like we do in Tennessee at (unintelligible) or something or grow crops because we cannot put a well in for contamination, then we are left with only looking at it for the pine trees.

So being federal, you own this property, Even with deed restrictions you've got to give us either a Phase I, II, or III audit. In this case, it's the seller who has to provide this liability, not necessarily the buyer's neglect of liability to due diligence. So it would really help if we knew what deed restrictions would be there to a more extent and also what we can use the land for. If I want to use it for applying 50 - - under the Code of Federal Regulations 503, if I want to use it for bio solid disposal, can I do so? Because it's adjacent to your other property. So the deed restrictions that you brought up were of immense concern about responding back to the future use and the disposal of roughly 
849,000 acres nationwide for - to be put back into - I understand from Washington, they would like to put it back mainly into public use to get the taces off of it. Maybe not so for the government, but for the local entities who lose the tax base. Thank you.

Response to Comment 3: The SRS Future. Use Project Repart was distributed to inform citizens of the planned future uses of the SRS. The recommendations that were presented in the report may change over time and will be discusced with the atakeholders. Deed reatrictions for federal property are not determined until the land is transferred to non-federal control. At the time of property transfer, the need for deed reatrictions will be evaluated. Due to natural attenuation, decay, etc, the conditions at specific areas may not warrant any deed restrictions. All legal requirements will be met at the time of property transfer. 
Responses to Comments by SCDHEC and the USEPA for the Record of Decision for the D-Area Burning/Rubble Pits (431-D and 431-1D) (U), WSRC-RP-96-867, Revision 0, Dated November 1996. Responses are in bole typeface.

SCDHEC Comments on the Record of Decision for the D-Area Burning/Rubble Pits (431-D and 4311D) (U), WSRC-RP-96-867, Revision 0, Dated November 1996. Comments received Jamuary 3, 1997 via FAX.

1) Page 19 of 26, Section IX, The Selected Remedy, the preferred action chosen is Institutional Controls (Alternative 2). This action will not address the risk associated with the groundwater or the COCs that exceeded the MCLs. The report should be revised and another action chosen.

Response 1) Clarification. The DBRP\& were constructed and placed in service in 1951. The water table aquifer at the DBRPs has been monitored since September 1983; the water table averaged 10 feet below surface (ranging from 6 to 15 feet below surface). Well DBP 2, the closest downgradient well is less than 120 feet from the south edge of BRP 431-D. Any constituent from the DBRP which will leach to groundwater should already have been detected in well DBP 2 (for instance, arsenic leached to groundwater from the pits should have reached DBP 2 in 14.8 years), the impacts to groundwater have generally been well below. MCLs.

The only constituents which have equaled or exceeded MCLs in the period of interest (1Q93 through 2Q96, 63 well quarters) are dichloromethane, gross alpha, and the total of radium-226 and radium228. Arsenic was modeled as a risk and hazard driver, however arsenic has only been detected twice in the DBP monitoring network; the December 1993 sample from well DBP-5 contained the higher value $0.044 \mathrm{mg} / \mathrm{L}$, which is below the $0.05 \mathrm{mg} / \mathrm{L} \mathrm{MCL}$. The following quarter when the well was resampled, arsenic was reported below detection limits of $0.002 \mathrm{mg} / \mathrm{L}$.

Dichloromethane (methylene chloride), a common laboratory artifact, was only reported in three soil samples in a total of 55 samples collected from the DBRP with a maximum of $v 0.06 \mathrm{mg} / \mathrm{Kg}$ (boring D341107 at a depth of $4.0-6.0$ feet). The remaining two values were $0.00732 \mathrm{mg} / \mathrm{Kg}(4.0-6.0$ $\mathrm{ft}$ in D43112) and JV0.0117 $\mathrm{mg} / \mathrm{Kg}(6.0-8.0 \mathrm{ft}$ in D43112). The " J" qualifier indicates that the analyte was detected below detection limits and that the reported value is an estimate; the "V" qualifier indicates that the analyte was also detected in the associated method blank, indicating laboratory contamination. The weighted average for dichloromethane in the waste interval, using half detection limits for non-detects, is $0.0079 \mathrm{mg} / \mathrm{Kg}$. These dichloromethane values do not constitute a sufficient source for significant groundwater contamination. Between 1095 and 3Q95, dichloromethane was detected in each of the DBP wells; the $0.005 \mathrm{mg} / \mathrm{L}$ MCL was erceeded only four times as follows:
upgradient well
DBP 3
DBP 2
$1 Q 95$
downgradient well
DBP 3
$2 Q 95$
upgradient well
DBP 5
2Q95
2095
$0.0077 \mathrm{mg} / \mathrm{L}$
$0.0088 \mathrm{mg} / \mathrm{L}$
$0.0056 \mathrm{mg} / \mathrm{L}$
$0.011 \mathrm{mg} / \mathrm{L}$

Given dichloromenthane's occurrence in both upgradient and downgradient samples and the fact that it is a typical laboratory contaminant, the occurrence of dichloromethane is interpreted as a laboratory artifact.

The MCL for gross alpha is $15 \mathrm{pCi} / \mathrm{L}$, this level may have been equaled or erceeded in the December 1993 sample from downgradient well DBP 2 (15 pCi $/ \mathrm{L} \pm 0.21 \mathrm{pCi} / \mathrm{L})$. This gross alpha anomaly occurred only once in a single well that had previously contained no detectable gross alpha. 
The $1976 \mathrm{MCL}$ for total radium is $5 \mathrm{pCiL}$; an increase to $20 \mathrm{pCi} / \mathrm{L}$ is being considered under proposed regulations (56FR33050). Total radium and the total of radium-226 and -228 have not exceeded the proposed 20 pCiL MCL since monitoring began at the DBRP in September 1983. The total of radium-226 and -228 in the groundwater has only erceeded $5 \mathrm{pCi} / \mathrm{L}$ one time since monitoring began at the DBRP. The only erceedance of the $1976 \mathrm{MCL}$ for total radium or the total of radium-226 and radium-228 occurred in the sample collected from well DBP 2 in December 1993 (the same sample which yielded the gross alpha anomaly); Ra-226 was $4.8 \mathrm{pCi} / \mathrm{L}$ and Ra-228 was 3.5 pCi/L (total 8.3 pCi/L). The relationship of the gross alpha and Ra-226/228 anomalies in the same sample suggests that these anomalies could be due to problems with laboratory or field sampling techniques.

The small number and low magnitude of these exceedances and the sporadic occurrence of the anomalies suggest that the probable condition is that no significant groundwater contamination has resulted from the DBRP. Thus no remedial action and a period of continued monitoring for confirmation is the appropriate action. The risk models and fate and transport models generated in the development of the Baseline Risk Assessment (BRA) are highly conservative. The models consider "J" and "V" qualified data with the same weight as data which does not have a qualifier. The reasonable maximum exposure level is the lower of the mean at the 95 percentile UCL or the marimum detected value for the constituent. The source does not suffer depletion or degradation (an infinite source). These conservative assumptions have exaggerated the calculated risks.

The proposed analyte list, derived from the BRA, included a number of modeled risk and hazard drivers which have not even been detected in the groundwater (Table 1). The Secondary MCL for manganese, $0.05 \mathrm{mg} / \mathrm{L}$, was exceeded 22 times with a marimum of $1.44 \mathrm{mg} / \mathrm{L}, 4 \mathrm{Q} 93$, DBP 2. Table 2 presents the modeled risks for these analytes and compares the modeled concentrations to current MCL's.

Dieldrin was identified as a modeled-DBRP-soils-to-groundwater ingestion risk driver to future residents, $81 \%$ of $8 \times 10^{-4}$ in Revision 0 of the BRA. Dieldrin was only detected two times out of 45 soil samples collected in the DBRP. The maximum value reported was J0.0165 mg/Kg in the 4 to 6 foot interval of boring 11, the "J" qualifier indicates that the analyte was recognized below detection limits and the value was estimated. The risk contribution of dieldrin was reevaluated in the BRA, Revision 1 and dieldrin was eliminated as a risk driver based on its high uncertainty of detection and low number of occurrences.

Tritium was recognized as a risk driver in the modeled-DBRP-soil-to-groundwater exposure pathway in the BRA. Tritium only exceeded the two times mean background screening level (5.26 pCi $/ g)$ in the DBRP soils seven times in 49 soil samples, the maximum value reported was $13.5 \mathrm{pCi} / \mathrm{g}$ from the 2 to 4 foot interval in boring 8. The maximum contaminant level for tritium is 20,000 $\mathrm{pCi} / \mathrm{L}$, the highest value of tritium reported from the groundwater was only $3400 \mathrm{pCi} / \mathrm{L}, 17 \%$ of the MCL. The maximum modeled-soil-to-groundwater concentration was $11,500 \mathrm{pCi} / \mathrm{L}$

The PAHs, HpCDD, OCDD, 1,1,2-TCA, 1,2-DCA, carbon disulfide, and chloroform have not been detected in groundwater. These constituents have very low solubilities in aqueous systems and tend to be strongly adsorbed to clays and humates in the soil; they are not readily transferred from soil to groundwater. Thus the modeled-DBRP-soil to groundwater risks are exaggerated. 
Table 1. Proposed Analyte List for Continued Groundwater Monitoring at the BRP

\begin{tabular}{lcc} 
Analyte & $\begin{array}{c}\text { Number of Times Detected } \\
\text { in Groundwater }\end{array}$ & $\begin{array}{c}\text { Number of Times } \\
\text { MCL Was Exceeded }\end{array}$ \\
\hline arsenic & 2 & 0 \\
benzene & 1 & 0 \\
benzo(a)anthracene & 0 & 0 \\
benzo(a)pyrene & 0 & 0 \\
benzo(b)fluoranthene & 0 & 0 \\
benzo(k)fluoranthene & 0 & 0 \\
chromium & 3 & 0 \\
chrysene & 0 & 0 \\
1,2-dichloroethane & 0 & 0 \\
dichloromethane & 18 & 4 \\
endrin & 0 & 0 \\
manganese & 38 & 0 \\
octachlorodibenzo-p-dioxin & 0 & 0 \\
PCB-1260 & 0 & 0 \\
total radium & 9 & 1 \\
1,1,2-trichloroethane & 0 & 0 \\
tritium & 11 & 0
\end{tabular}

Table 2. Comparison of Modeled Risks and Modeled Concentrations to Current MCLs Modeled

\begin{tabular}{|c|c|c|c|}
\hline Analyte & $\begin{array}{l}\text { Risl//HQ } \\
\text { (Ingestion) }\end{array}$ & $\begin{array}{l}\text { Concen } \\
(\mathrm{m} / \mathrm{L})\end{array}$ & $\begin{array}{l}\mathrm{MCL} /(\mathrm{SMCL}) \\
(\mathrm{mg} / \mathrm{L})\end{array}$ \\
\hline $\begin{array}{l}\text { arsenic } \\
\text { benzene }\end{array}$ & $1.35 \mathrm{E}-05$ & 0.00052 & 0.05 \\
\hline benzo(a)anthracene & $1.03 \mathrm{C}-05$ & 0.000095 & 0.0001 \\
\hline benzo(a)pyrene & $2.12 \mathrm{E}-05$ & 0.000194 & 0.0002 \\
\hline benzo(b)fluoranthene & $2.77 \mathrm{E}-05$ & $0.000255^{*}$ & 0.0002 \\
\hline benzo(k)fuoranthene & $1.13 \mathrm{E}-06$ & 0.000011 & 0.0002 \\
\hline chromium & $\mathrm{HQ}=0.031$ & 0.0017 & 0.05 \\
\hline chrysene & $1.85 E-09$ & 0.00000056 & 0.0002 \\
\hline 1,2-dichloroethane & $1.56 \mathrm{E}-05$ & $0.0115^{\star}$ & 0.005 \\
\hline dichloromethane & $3.4 \mathrm{E}-06$ & $0.0305^{*}$ & 0.005 \\
\hline endrin ketone & -- & $0.00034^{*}$ & 0.0002 \\
\hline manganese & measured. & $1.44^{*}$ & $(0.05)$ \\
\hline OCDD & 1.69E-06 & $7.56 \mathrm{E}-10$ & $3.0 \mathrm{E}-08$ \\
\hline $\begin{array}{l}\text { PCB-1260 } \\
\text { total radium }\end{array}$ & $7.87 \mathrm{E}-06$ & 0.0000687 & 0.0005 \\
\hline $\begin{array}{l}\text { 1,1,2-trichloroethane } \\
\text { tritium }\end{array}$ & $\begin{array}{l}7.29 \mathrm{E}-06 \\
2.0 \mathrm{E}-05\end{array}$ & $\begin{array}{l}0.0086^{\star} \\
11,500 \mathrm{pCi} / \mathrm{L}\end{array}$ & $\begin{array}{l}0.005 \\
20,000 \mathrm{pCi} / \mathrm{L}\end{array}$ \\
\hline
\end{tabular}


2) Page 8 of 26, Section VI (Summary of Operable Unit Risks) states that a COC contributes to either a cumulative site carcinogenic risk greater than $1.0 \times \mathrm{E}-4$, or a hazand index greater than one. The Department's policy states that a COC exists if the risk is greater than $1.0 \times \mathrm{E}-6$, and the ROD should be revised accordingly.

Response 2) Agree. The ROD will be revised to incorporate SCDHEC's policy in defining COC2. "A COC contributes significantly to a pathway that contributes to either a cumulative site carcinogenic risk greater than $1.0 \times 10^{-6}$ or a hazard index greater than 1.0." 
USEPA General comments on the Record of Decision for the D-Area Burning/Rubble Pits (431-D and 431-1D) (U), WSRC-RP-96-867, Revision 0, Dated November 1996. Comments received January 14, 1997.

1) Include post-ROD implementation schedules for the subject RODs.

As agreed to among the parties, all RODs, except RODs for no action, will include post-ROD implementation schedules. These schedules should include all post-ROD primary documents and their dates for submission. The post-ROD schedule for RODs which do not address the full scope of the operable unit addressed in the approved RFI/RI work plan (e.g., additional work necessary for a medium impacted by the operable unit source) shall include the following milestones for the additional RIFS additional work:

1) date for submission of the work plan;

2) major milestone Field Start Date; and

3) major milestone ROD Date.

Response 1) Clarification. SRS is preparing an implementation plan and generic schedule for Institutional Control waste sites. The program will include details on

1) deed notification and restrictions for possible future non-government owners,

2) access controls,

3) annual field walkdowns, and

4) groundwater monitoring and reporting.

Section XII of the ROD includes a schedule for the post-ROD Corrective Measures Implementation/Remedial Action Report.

USEPA Comments on the Record of Decision for the D-Area Burning/Rubble Pits (431-D and 4311D) (U), WSRC-RP-96-867, Revision 0, Dated November 1996. Comments received December 30, 1996 via FAX.

1) On page 19, Section $\mathrm{XX}$, column two, the text states that ... "The data from the annual sampling events will be included in the five year ROD reviews." It is unclear whether the Department of Energy-Savannah River Site (DOE-RSS) will submit the annual data to the EPA and the South Carolina Department of Health and Environmental Control (SCDHEC) for review prior to conducting the five year review. This needs to be clarified and EPA should receive this information for review as it is compiled and not wait until the five year review period of the ROD.

Response 1) Clarification. Please see the response to the January 14, 1997 USEPA general comment. 